\title{
A STRATEGIC MODEL OF MACRO-ECONOMIC AND SUPPLY CHAIN FACTORS THAT INFLUENCE THE DECISION-MAKING PROCESS OF SA RETAILERS WHEN EXPANDING THEIR FOOTPRINT IN AFRICAN COUNTRIES
}

\author{
L. Engelbrecht ${ }^{1 *} \&$ A.C.J. van Rensburg ${ }^{1}$
}

\section{ARTICLE INFO}

\section{Article details}

Submitted by authors 28 Mar 2018

Accepted for publication 17 Sep 2018

Available online 10 Dec 2018

\section{Contact details}

Corresponding author

lizet.engelbrecht@gmail.com

\section{Author affiliations}

1 Department of Industrial

Engineering, Stellenbosch

University, South Africa

DOI

http://dx.doi.org/10.7166/29-4-1956
ABSTRACT

As part of the era of globalisation, the foreign market expansion of retailers is a trend that draws the attention of economists and researchers alike, and is an ever-expanding field of scholarly review. Africa is no exception to the process of globalisation, and as the local South African retail market becomes saturated with increasing levels of competition, large retailers are gradually experiencing more pressure to expand their footprint into other African countries. Foreign market expansion is a business decision that requires a structured analytical framework to assist in the decision-making efforts of potential foreign investors. Models can be synthesised to assess and prioritise which market, country, or region to enter next; what the opportunities and risk of such a move will be; and what the business case would look like in terms of cost and benefit. Only a limited amount of literature discusses this topic in the specific context of South African retailers, creating an opportunity for further research. This paper presents a strategic decision-support model to assist South African retailers in making well-informed decisions about which sub-Saharan African market to enter next. A holistic approach is taken that covers various disciplines, including supply chain management, economics of development, and financial management.

\section{OPSOMMING}

Die uitbreiding na buitelandse markte as deel van die globaliseringsera, is ' $n$ tendens wat die aandag van ekonome en navorsers trek en is ' $n$ studieveld waarop deskundiges toenemend fokus. Afrika is geen uitsondering in die globaliseringsproses nie, en soos die plaaslike Suid-Afrikaanse kleinhandel ' $n$ versadigingspunt in mededingingsvlakke bereik, word groot kleinhandelaars gedwing om hulle in ander Afrika-lande te vestig. Uitbreiding na buitelandse markte is ' $n$ besigheidsbesluit wat op ' $n$ analitiese raamwerk baseer moet word ten einde beleggers te help in hulle besluitnemingsproses. Modelle kan saamgestel word om vas te stel watter mark, land of streek vervolgens 'n prioriteit behoort te wees vir besigheidsuitbreiding; watter geleenthede en risiko so ' $n$ skuif inhou; en wat die besigheidsplan ten opsigte van koste en voordele inhou. Daar is beperkte navorsing oor dié onderwerp in die SuidAfrikaanse kleinhandelskonteks, wat 'n gaping skep vir verdere navorsing. Hierdie artikel bied 'n strategiese besluitondersteuningsmodel om Suid-Afrikaanse kleinhandelaars te help om ' $n$ ingeligte besluit te neem na watter sub-Sahara Afrika mark hulle volgende moet uitbrei. 'n Holistiese benadering word voorgehou wat verskeie dissiplines soos voorsieningskettingbestuur, ontwikkelingsekonomie en finansiële bestuur insluit. 
As the local South African retail market becomes saturated with increasing levels of competition, large retailers are gradually experiencing more pressure to consider expansion into emerging African markets. As Marshall states in Prisoners of geography [1], "There is a new scramble for Africa in this century, but this time it is two-pronged. There are well-publicised outside interests in the competition for resources, but there is also the 'scramble within', and South Africa intends to scramble fastest and furthest".

Across the disciplines of supply chain management and the economics of development, four main constructs are evident that give an indication of the variables to assess when making these expansion decisions, from a supply chain strategy viewpoint. These constructs are opportunity, risk, benefit, and cost. This conclusion is confirmed by Gillis et al. [2] and Levi, Kaminsky \& Levi [3]. Combining these four constructs into a single solution makes this a complex problem to solve, as it requires a mix of quantitative and qualitative variable inputs, and stretches across multiple fields of study (supply chain management, financial management or 'engineering economics', economic development, and marketing). The aim of this article is to introduce a decision-support model to guide retailers in their foreign market expansion efforts by taking a holistic cross-disciplinary approach.

First, the rationale of the research is discussed, followed by the definition of the key constructs. Then all the identified input variables are listed and discussed in the context of the tools and techniques that were used during the model synthesis. The proposed strategic input-output model is presented as two sub-models, and model validation is discussed. The article concludes with a summary of the research findings and the potential benefits of its application.

\section{BACKGROUND}

Macro-economic data show that many African countries have experienced an improvement in factors such as gross domestic product (GDP), labour productivity, democracy, infrastructure, foreign direct investment, and job creation, as well as a decline in foreign debt and inflation, over the past 10 years [4]. Foreign investors find emerging markets attractive, as evidenced by the fact that emerging market economies account for more than half of current global foreign direct investment (FDI). A literature review compiled by Gbadamosi [4] on African development in recent years reinforces statements that African economies are on the rise, and that their economic growth has been positive since the 1980s. Combined with an increase in urbanisation and an expanding middle class, many African countries are now in a position to attract potential foreign investors, especially in the consumer products and retail sector. This market opportunity is confirmed in reports by Ernst \& Young [5], ATKearney [6], and PwC [7].

\subsection{Rationale of the research}

With the rise of investment opportunities across Africa, there is a need for a structured analytical framework to assist potential foreign investors in their decision-making efforts, as highlighted by both Brouthers [8] and Khanna and Palepu [9]. Akbar, Bortoluzzi \& Tracogna [10] comment that making informed decisions about expansion into emerging markets is a complex exercise, and Ahsan \& Musteen [11] highlight that there are many opportunities for further research on uncertainty during market entry. Models can be synthesised to assess and prioritise which market, country, or region to enter next; what the opportunities and risk of such a move will be; and what the business case would look like in terms of cost and benefit. Decisions to enter African markets are currently based on ill-informed opinion, and not on empirical data or rigorous models [5]. Limited literature is available to discuss this issue in the specific context of South African retailers.

The objective of this paper is to construct a decision-support model for retail expansion into foreign markets, specifically for South African retailers looking to enter sub-Saharan African countries. The study identifies various industrial engineering tools and techniques, and all the qualitative and quantitative variables that should be considered during foreign market expansion. The identified tools and techniques are synthesised to present a strategic input-output model based on the four key constructs of opportunity, risk, benefit, and cost. 
To reduce the complexity of the discussion, the main thought addressed by the research - informed decision-making when considering expansion into an emerging sub-Saharan African market, specifically in the retail sector - will be referred to from now on simply as the 'expansion decision' or 'investment decision'.

\subsection{Key concepts and definitions}

The constructs of 'global supply chain strategy', 'foreign market entry', 'engineering economics', and 'systems thinking' are identified as integral to the research problem, and are defined in this section.

Frazelle [12] and Levi et al. [3] agree that a supply chain is a complex system, and system-wide elements should be kept in mind. 'Supply chain strategy' is the approach of taking strategic steps to align supply chain operations with the goals of the company, such as growing market share and increasing profit. A physical supply chain consists of multiple nodes of suppliers, warehouses, distribution centres, retail outlets, and its transportation logistics [3]. Coyle et al. [13] explain that, in a global supply chain, these nodes span national borders.

'Foreign market' entry is the efforts of a business to expand its footprint across borders into a market with which it has not had trade relationships in the past.

'Engineering economics' is the study and analysis of economic problems faced by engineers, specifically in the light of making complex investment decisions. Kossiakoff et al. [14] explain that complex problems require multiple inputs and a deeper level of research, with outputs presented to stakeholders in a simplified way so that they can make a well-informed decision.

A system is a complex whole consisting of various parts; and its working depends on the interaction among the parts. Systems concepts have been refined in various disciplines, as is evident in the development of systems principles, systems thinking, and systems dynamics by Forrester [15]. Jackson [16] expands on this research by explaining how 'systems thinking' presents a holistic approach to complex issues, as opposed to the theory of reductionism, which looks at the parts in isolation. The decision about foreign market expansion is a complex one, and contains a high level of uncertainty in its variables. Ahsan \& Musteen [11] claim that the issue of uncertainty has been one of the most prominent topics in the research field of foreign market entry, and they define it as the lack of information about the likelihood of an outcome, and the inability to determine which data is most relevant during decision-making. In the context of engineering economics, Newnan, Eschenbach \& Lavelle [17] emphasise that, in most cases, future costs, demand, and revenue will be uncertain, and as part of the data collection process, a range of likely values must be determined.

\section{INPUT VARIABLES, TOOLS, AND TECHNIQUES}

Even though researchers have studied foreign market entry for years, Brouthers [8] stresses that there is still a clear gap in investigating which tools would be most apt for the synthesis of rigorous models in assisting decision-making during internationalisation. In order to provide measurable outcomes, decisions should be based on quantifiable factors without the focus being placed on only one or two decision variables. A systems thinking approach is used to synthesise various model design methodologies in a creative and holistic manner. Many studies have addressed the research topic from the isolated viewpoint of a single discipline (including supply chain management, the economics of development, or financial management), but few papers approach the problem with an all-encompassing systems view. This section presents all the input and output variables that are identified as critical for inclusion in such a decision-support model, and the tools and techniques that are used to translate the input variables into satisfactory outputs.

\subsection{Quantitative and qualitative input variables}

Research started with the four key constructs of opportunity, risk, benefit, and cost. Benefit and cost variables are easily quantifiable financial measures, whereas opportunity and risk are of a more qualitative nature, and should be converted into quantitative measures to make the four constructs comparable with one another.

An 'opportunity' variable is defined as an indicator that would attract an investor to a foreign market, such as the market size or economic growth rate. A 'risk' variable is an indicator of 
uncertainty that reduces the confidence of an investor in selecting a country for foreign investment, such as poor corporate governance or high levels of corruption.

In order to calculate an investment's financial returns in terms of 'benefit' and 'cost', the quantitative inputs are assessed by taking a distribution network design (DND) approach. The inputs required by the decision-support model are identified (and listed in no particular order) as being annual estimated unit demand, cost of goods sold, inbound transportation cost (including cost of importing), outbound distribution transportation cost, other operational costs, and total assets (fixed and current). Using these variables as inputs to a basic strategic profit model, various ratios can now be calculated for making a well-informed investment decision. These ratios include gross margin, total operating cost, net income, net profit margin, and return on assets (or return on investment).

Even though a financial analysis is critical to investment decisions, Coyle et al. [13] highlight that 'benefit' and 'cost' should not be calculated in isolation, but that the 'opportunity' and 'risk' measures of the investment should be considered in parallel. Thus, part of the research aim is to compile a comprehensive list of qualitative variables that are well representative of the 'opportunity' and 'risk' presented by a foreign market investment decision. According to Brouthers [8], sites and indices that provide high-quality secondary data on regulatory and normative environments include the global competitiveness index, the economic and investment potential index, the customer demand potential index, the African Retail Development Index, the Ibrahim Index of African Governance, the Economic Freedom Index, and the Euromoney Country Risk Survey $[18,19,20,21]$. Through an iterative process of refining literature samples, seven macro-economic variables are identified that represent well the 'opportunity' for foreign market expansion by a retailer. These are listed (in no particular order) as being GDP, the annual growth rate of GDP, the annual growth rate of the size of the population, the size of foreign direct investment, the perceived competitiveness of the country, GDP per capita, and the size of the population in urban regions.

Another list is compiled to convey seven macro-economic variables that adequately represent the 'risk' that retailers face when entering a foreign market. These are listed (in no particular order) as being the adult literacy rate, ranking on the corruption perceptions index, degree of economic freedom, degree of corporate governance, ranking on the logistics performance index, distance to frontier for trading across borders, and ranking on the ease of doing business index [20, 22, 23, 24].

\subsection{Tools and techniques}

A systems thinking approach leads to the combination of a list of industrial engineering tools and techniques that are most apt for building the decision-support model, including Microsoft Excel applications, the analytical hierarchy process (AHP), a supply chain distribution network design, a strategic profit model, Monte Carlo simulation, sensitivity analysis, and what-if analysis. Each of the tools is integrated into the final proposed decision-support model, providing stakeholders with a simplified approach to a complex investment decision.

\subsubsection{Distribution network design (DND) and strategic profit model (SPM)}

Taking a DND approach, multiple supply chain variables have been identified for inclusion in the decision-support model, including various costs, the estimated unit demand, and the total assets. From these variable inputs, ratios can be calculated that are vital to making an informed expansion decision, such as the gross margin, total operational cost, net income, net profit margin, asset turnover, and - most importantly - the return on assets or return on investment.

By considering the strategic profit model (SPM) in Figure 3-1, good measures for quantifying the benefit of the investment would be the ratio for net profit margin (NPM) and the return on assets (ROA). Llamasoft LogicTools LogicNet Plus ${ }^{\circledR}$ XE (Llamasoft) software [25] could be used to simulate multi-objective optimisation for various scenarios. During distribution network design, a simulator is constructed to compare various pre-defined scenarios with one another to reflect the costs and benefits of each potential investment. Before the distribution network design can be undertaken, the selection of foreign markets that are considered to have a high market potential first need to be identified. This is done by taking an analytical hierarchy process approach. 


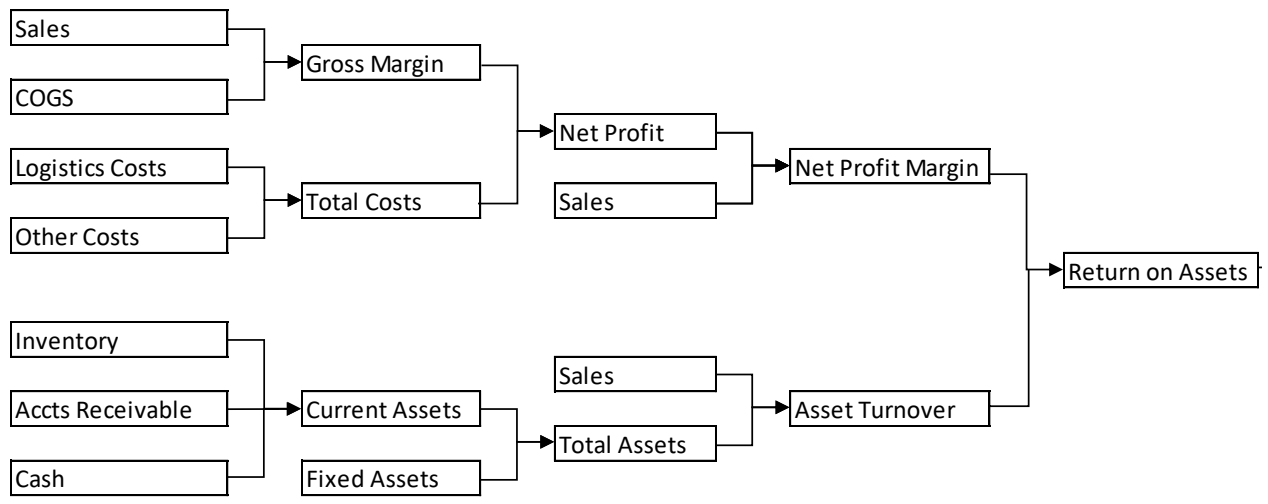

Figure 3-1: Strategic profit model [13]

\subsubsection{Analytical hierarchy process (AHP)}

Saaty [26] first introduced AHP as a useful approach to synthesising quantitative and qualitative variables for complex decision-making. The approach is based on multi-criteria decision-making, using the experiential knowledge of the stakeholders of the decision. The network structure proposed by Saaty [26] is especially relevant to this research problem, as it is useful in constructing decision outcomes based on the four main constructs of opportunity, risk, benefit, and cost. AHP is a method of pair-wise comparison, where input from a team of subject matter experts (SMEs) is required to weigh each variable against the next using a simple ratio scale. Vargas [27] believes that the experiential knowledge of SMEs during decision-making is just as important as the data used to make the decision. The tool selected for AHP calculations in this study is a spreadsheet template developed by Goepel [28] that has been made available for public use.

\subsubsection{What-if analysis, sensitivity analysis, and Monte Carlo modelling}

Geoffrion \& Van Roy [29] explain that the responsibility of a decision-making model is not only to present recommendations, but also to justify them convincingly. A comparative study must be done to compare model outcomes with different possible futures. According to Savage [30], a what-if analysis is the process of experimenting with the model variables by keeping all but some input constant, and then analysing the deviation of outputs to understand the impact and relationships of the input variables better. Newnan et al. [17] explain that a variable is considered to be 'sensitive' if it greatly impacts the output of the alternative selection. Where inputs cannot be gathered through primary data collection, random variables are simulated to test the proposed model design. Monte Carlo simulation is a helpful tool to synthesise data points under uncertainty by using algorithms for repeated random sampling across a data set with a specified probability distribution [30].

\section{THE PROPOSED DECISION-SUPPORT MODEL}

A combination of the scientific method and the systems thinking approach is used to develop a decision-support model. This approach allows for a variety of tools and techniques to be combined to ensure that all the qualitative and quantitative variables identified throughout the research process are included in the model. The four main model outputs are derived from two fields of study: 'opportunity' and 'risk' variables are derived from the study of macro-economics, while 'benefit' and 'cost' variables are derived from the fields of supply chain management and financial management. Likewise, the model development is deconstructed into two development sprints: 'Sub-model 1' and 'Sub-model 2'. The model design is described in more detail by using a hypothetical scenario of a South African retailer looking to expand into one sub-Saharan African market in which the retailer does not yet have a business footprint.

\subsection{Sub-model 1: Literature content analysis and AHP}

As part of model development, the system under investigation is mapped on a strategic level. A thorough 'content analysis' is conducted across a broad spectrum of literature, and an exhaustive list of possible variables is reduced to the most relevant input parameters. Thereafter historical secondary data is collected to conduct a correlation analysis on each of the selected variables. A 
rigorous literature content analysis is conducted to refine the exhaustive list of variables identified during the literature review (which presented over 85 possible variables for consideration). Word counts and frequency analyses are conducted to validate and shortlist the variables that should be included in the final model. Table 4-1 lists the final 14 selected variables: seven that represent market opportunity well, and seven that reflect the risk of entering a foreign market.

Table 4-1: Refined list of seven opportunity variables and seven risk variables for further analysis

\begin{tabular}{|c|c|c|c|}
\hline CODE & INDICATOR / VARIABLE & $\begin{array}{l}\text { OPPORTUNITY } \\
\text { VS RISK }\end{array}$ & SEARCH TERMS FOR LITERATURE STUDY \\
\hline GDP & $\begin{array}{l}\text { GDP based on PPP valuation } \\
\text { (USD million) }\end{array}$ & OPPORTUNITY & GROSS DOMESTIC PRODUCT / GDP \\
\hline GDP/CAP & $\begin{array}{l}\text { GDP per capita (PPP } \\
\text { valuation) }\end{array}$ & OPPORTUNITY & GDP PER CAPITA / GNI PER CAPITA \\
\hline POPGROW & $\begin{array}{l}\text { Population growth rate (per } \\
1000 \text { ) }\end{array}$ & OPPORTUNITY & POPULATION GROWTH \\
\hline POPURBAN & Urban population & OPPORTUNITY & URBANISATION / URBAN POPULATION SIZE \\
\hline COMPETITIVE & $\begin{array}{l}\text { Competitiveness indicator } \\
2010-2014(\%)\end{array}$ & OPPORTUNITY & $\begin{array}{l}\text { COMPETITIVENESS / DIVERSIFICATION / EXPORT } \\
\text { GROWTH }\end{array}$ \\
\hline FDIINFLOW & FDI inflows per historical year & OPPORTUNITY & FOREIGN DIRECT INVESTMENT / FDI INFLOW \\
\hline GDPGROW & $\begin{array}{l}\text { Annual real GDP growth } \\
\text { (average over 2008-2016) }\end{array}$ & OPPORTUNITY & GDP GROWTH / ECONOMIC GROWTH \\
\hline LITERACYADULT & $\begin{array}{l}\text { Estimated adult literacy rate, } \\
2010-2015 \text { (people over 15) }\end{array}$ & RISK & ADULT LITERACY \\
\hline LOGPERFINDEX & Logistics Performance Index & RISK & LOGISTICS / INFRASTRUCTURE \\
\hline EASEBUSINESS & $\begin{array}{l}\text { Ease of doing business } \\
\text { ranking }\end{array}$ & RISK & EASE OF DOING BUSINESS \\
\hline ECONOFREEDOM & Economic freedom & RISK & ECONOMIC FREEDOM / DEMOCRACY \\
\hline GOVERNANCE & Governance & RISK & GOVERNANCE \\
\hline CORRUPT & $\begin{array}{l}\text { Corruption Perceptions Index } \\
2013-2015\end{array}$ & RISK & CORRUPTION \\
\hline TRADEBORDER & $\begin{array}{l}\text { Ease of trading across } \\
\text { borders }\end{array}$ & RISK & EASE OF TRADE / CROSS BORDER TRADE \\
\hline
\end{tabular}

Secondary data was collected from reputable sources (including the World Economic Forum [18], the Ibrahim Index of African Governance [19], the PRS Group [21], and the World Bank [24]) for each of the 14 identified variables, for each of the countries included in the scope. Data analysis consists of statistical summaries and a statistical correlation exercise.

The next step of model development is the application of AHP to determine a final comparative rating for 'market opportunity' and 'risk of market entry' for each sub-Saharan African country. The goal of this step is to reduce the large sample size of 43 countries to only a few options for investment consideration. From data collection in the form of a questionnaire, pairwise comparisons are made by SMEs to determine the perceived relative importance of variables against one another. The comparison is based on the 'fundamental scale of Saaty' - a numerical scale of nine deterministic points [26].

\subsubsection{Validation of Sub-model 1: A case study}

Validation of Sub-model 1 is done in the form of a case study. An intentional sample of SMEs is selected to take part in the case study. (An SME is an individual who would typically be considered a stakeholder in a scenario where a supply chain investment decision is to be made.)

A questionnaire is designed to collect information from the sample of individuals, starting with introductory questions to collect data on the individuals' experience and current position held in their company. A survey of consumer finances (SCF) reference question is included to measure the individuals' 'attitude towards risk' to ensure construct validity [31]. The next section allows each research participant to list and rank the top ten sub-Saharan African countries they would choose for foreign market expansion, based on their personal experience and subject matter expertise. The final two sections of the questionnaire consist of attitude scales for pairwise comparison of variables identified; first to estimate market opportunity, and thereafter to estimate the potential risk of market entry within the scope and context of this specific study. This gives the research participant's personal view on the perceived importance of certain macro-economic variables compared with one another. 
Questionnaire feedback is used to test Sub-model 1 by applying AHP to the data collected and then solving for the Eigenvector. Further data analysis is conducted across the responses received to compare the perceived opportunity of certain sub-Saharan Africa markets with the perceived risk of market entry. Table 4-2 summarises each individual's consistency ratio (CR) for the 'opportunity' and 'risk' slide scales, which can now be compared with the final aggregated results as shown in Table 4-3 (with $\mathrm{n}=$ number of criteria, and $\mathrm{N}=$ number of participants).

Table 4-2: Individual CRs for 'opportunity' and 'risk' slide scales

\begin{tabular}{|l|l|l|l|l|}
\hline PARTICIPANT & $\mathbf{n}$ & $\mathbf{N}$ & $\begin{array}{l}\text { 'OPPORTUNITY' } \\
\text { CONSISTENCY } \\
\text { RATIO }\end{array}$ & $\begin{array}{l}\text { 'RISK' } \\
\text { CONSISTENCY } \\
\text { RATIO }\end{array}$ \\
\hline 1 & 7 & 1 & $23 \%$ & $8 \%$ \\
\hline 2 & 7 & 1 & $6 \%$ & $16 \%$ \\
\hline 3 & 7 & 1 & $11 \%$ & $8 \%$ \\
\hline 4 & 7 & 1 & $10 \%$ & $10 \%$ \\
\hline 5 & 7 & 1 & $28 \%$ & $27 \%$ \\
\hline & Median: & 0.11 & 0.10 \\
& $80^{\text {th }}$ percentile: & 0.24 & 0.18 \\
\end{tabular}

Table 4-3 summarises the statistics compiled during AHP conducted across seven variables $(n=7)$ and a sample of five participants $(\mathrm{N}=5)$. An input consensus of 57 per cent is reached among the participants across the 'opportunity' variables and 66 per cent across the 'risk' variables. These results give a clear indication of how the consistency ratio has improved by taking a combined AHP view (as opposed to taking an average value for the individual results). For the 'opportunity' variables, the average $C R$ over the individual outputs results in $C R=0.16$, whereas the $C R$ for the combined results using AHP gives a much more desirable $C R=0.03$. Similarly, the average $C R$ across individual outputs of the risk variables results in $C R=0.14$, whereas the $C R$ for the combined results using AHP gives a value of $C R=0.016$. From these results, it is evident that the use of the balanced scale improves consistency.

Table 4-3: Aggregate results when a combined view is taken using AHP

\begin{tabular}{|l|l|l|l|l|l|l|}
\hline & $\mathbf{n}$ & $\mathbf{N}$ & CONSENSUS & ALPHA & GCI & CR \\
\hline 'OPPORTUNITY' & 7 & 5 & $57.0 \%$ & 0.15 & 0.12 & $3.3 \%$ \\
\hline 'RISK' & 7 & 5 & $66.2 \%$ & 0.20 & 0.06 & $1.6 \%$ \\
\hline
\end{tabular}

Table 4-4 and Table 4-5 below summarise the final weights assigned to each variable per individual, based on the row geometric mean method (RGMM). The tables show the output for individuals one to five, and the output of the combined results. The additional columns to the right show how results of an average value (calculated for each variable across the five participants' outputs) differ from the combined output result calculated by using the RGMM approach.

Final results for the aggregate weighted importance of the 'opportunity' and 'risk' variables are shown in Table 4-6 and Table 4-7 respectively, derived by solving the Eigenvector. From the results in Table 4-6, it is concluded that the participants in the case study consider the variable of GDP growth as the most important variable to take into consideration during foreign market expansion. GDP growth is thus assigned the greatest weight (of 24 per cent) for further calculation of the market attractiveness of the various sub-Saharan African countries. The second-highest weight is assigned to the variable of GDP per capita at 22 per cent, then the variable for FDI inflow at 13 per cent.

From the results in Table 4-7, it is concluded that the participants consider the variable representing the 'ease of doing business' as the most important variable for indicating the potential risk of foreign market entry (with a weight of 19.3 per cent). The second-highest weight is assigned to the 'risk' variable that indicates the prevalence of corruption (at 19.2 per cent), then the variable that measures the logistics performance (at 14 per cent). 
Table 4-4: Weighted outputs for each 'opportunity' variable by using the row geometric mean method (RGMM)

\begin{tabular}{|c|c|c|c|c|c|c|c|c|c|}
\hline \multirow{2}{*}{$\begin{array}{l}\text { 'OPPORTUNITY' } \\
\text { VARIABLE }\end{array}$} & \multicolumn{5}{|c|}{ Individual Participant Results } & \multirow{2}{*}{$\begin{array}{c}\text { Combined } \\
\text { Results } \\
\text { (RGMM) }\end{array}$} & \multirow{2}{*}{$\begin{array}{l}\text { Ranking } \\
\text { (based on } \\
\text { combined) }\end{array}$} & \multirow[b]{2}{*}{ Average } & \multirow{2}{*}{$\begin{array}{l}\text { Standard } \\
\text { deviation }\end{array}$} \\
\hline & 1 & 2 & 3 & 4 & 5 & & & & \\
\hline GDP & $41 \%$ & $7 \%$ & $5 \%$ & $6 \%$ & $17 \%$ & $13.0 \%$ & 4 & $15 \%$ & $15 \%$ \\
\hline GDPGROW & $18 \%$ & $20 \%$ & $18 \%$ & $36 \%$ & $13 \%$ & $24.0 \%$ & 1 & $21 \%$ & $9 \%$ \\
\hline POPGROW & $16 \%$ & $4 \%$ & $8 \%$ & $13 \%$ & $16 \%$ & $12.2 \%$ & 5 & $11 \%$ & $5 \%$ \\
\hline FDIINFLOW & $11 \%$ & $13 \%$ & $17 \%$ & $20 \%$ & $4 \%$ & $13.4 \%$ & 3 & $13 \%$ & $6 \%$ \\
\hline COMPETITIVE & $6 \%$ & $6 \%$ & $29 \%$ & $7 \%$ & $4 \%$ & $9.7 \%$ & 6 & $11 \%$ & $10 \%$ \\
\hline GDP/CAP & $4 \%$ & $34 \%$ & $19 \%$ & $16 \%$ & $41 \%$ & $21.6 \%$ & 2 & $23 \%$ & $14 \%$ \\
\hline POPURBAN & $3 \%$ & $17 \%$ & $4 \%$ & $3 \%$ & $6 \%$ & $6.1 \%$ & 7 & $7 \%$ & $6 \%$ \\
\hline
\end{tabular}

Table 4-5: Weighted outputs for each 'risk' variable by using the row geometric mean method (RGMM)

\begin{tabular}{|c|c|c|c|c|c|c|c|c|c|}
\hline \multirow{2}{*}{$\begin{array}{c}\text { 'RISK' } \\
\text { VARIABLE }\end{array}$} & \multicolumn{5}{|c|}{ Individual Participant Results } & \multirow{2}{*}{$\begin{array}{l}\text { Combined } \\
\text { Results } \\
\text { (RGMM) }\end{array}$} & \multirow{2}{*}{$\begin{array}{c}\text { Ranking } \\
\text { (based on } \\
\text { combined) }\end{array}$} & \multirow[b]{2}{*}{ Average } & \multirow[b]{2}{*}{$\begin{array}{l}\text { Standard } \\
\text { deviation }\end{array}$} \\
\hline & 1 & 2 & 3 & 4 & 5 & & & & \\
\hline LITERACYADULT & $36 \%$ & $16 \%$ & $19 \%$ & $4 \%$ & $3 \%$ & $12.3 \%$ & 5 & $16 \%$ & $14 \%$ \\
\hline CORRUPT & $10 \%$ & $12 \%$ & $24 \%$ & $11 \%$ & $42 \%$ & $19.2 \%$ & 2 & $20 \%$ & $14 \%$ \\
\hline ECONOFREEDOM & $17 \%$ & $16 \%$ & $13 \%$ & $16 \%$ & $4 \%$ & $13.8 \%$ & 4 & $13 \%$ & $5 \%$ \\
\hline GOVERNANCE & $10 \%$ & $12 \%$ & $4 \%$ & $19 \%$ & $7 \%$ & $10.7 \%$ & 7 & $10 \%$ & $6 \%$ \\
\hline LOGPERFINDEX & $12 \%$ & $9 \%$ & $5 \%$ & $20 \%$ & $21 \%$ & $14.1 \%$ & 3 & $13 \%$ & $7 \%$ \\
\hline TRADEBORDER & $9 \%$ & $13 \%$ & $7 \%$ & $11 \%$ & $8 \%$ & $10.7 \%$ & 6 & $9 \%$ & $2 \%$ \\
\hline EASEBUSINESS & $7 \%$ & $24 \%$ & $27 \%$ & $20 \%$ & $15 \%$ & $19.3 \%$ & 1 & $18 \%$ & $8 \%$ \\
\hline
\end{tabular}

Table 4-6: Final result of aggregate weighted 'opportunity' variables

\begin{tabular}{|l|l|c|c|}
\hline \multicolumn{1}{|c|}{ Criteria } & \multicolumn{1}{|c|}{ Description } & Weight & Rank \\
\hline GDP & GDP based on PPP valuation & $12.95 \%$ & 4 \\
\hline GDPGROW & Annual real GDP growth & $23.95 \%$ & 1 \\
\hline POPGROW & Population growth (\%) & $12.22 \%$ & 5 \\
\hline FDIINFLOW & FDI inflow (USD million) & $13.44 \%$ & 3 \\
\hline COMPETITIVE & Global competitiveness effect (\%) & $9.73 \%$ & 6 \\
\hline GDP/CAP & GDP per capita (PPP valuation, USD) & $21.60 \%$ & 2 \\
\hline POPURBAN & Total urban population (thousands) & $6.11 \%$ & 7 \\
\hline
\end{tabular}

Table 4-7: Final result of aggregate weighted risk variables

\begin{tabular}{|l|l|c|c|}
\hline Criteria & \multicolumn{1}{|c|}{ Description } & Weight & Rank \\
\hline LITERACYADULT & Estimated adult literacy rate (\%) (age > 15) & $12.34 \%$ & 5 \\
\hline CORRUPT & Corruption perception index (CPI) & $19.17 \%$ & 2 \\
\hline ECONOFREEDOM & Economic freedom score & $13.80 \%$ & 4 \\
\hline GOVERNANCE & Mo Ibrahim Index of African Governance & $10.65 \%$ & 7 \\
\hline LOGPERFINDEX & Logistics performance index & $14.06 \%$ & 3 \\
\hline TRADEBORDER & Distance to frontier: Trade across borders & $10.74 \%$ & 6 \\
\hline EASEBUSINESS & Ease of doing business ranking & $19.25 \%$ & 1 \\
\hline
\end{tabular}

Using these weighted variables as inputs, the results are tested against the macro-economic secondary data collected for each of the variables. Figure 4-1 and Figure 4-2 below display the final 
outputs of the case study. The first shows the top five countries as ranked by the weighted variables for opportunity of foreign market entry, and the second figure shows the top five countries as ranked by the perceived risk of foreign market entry.

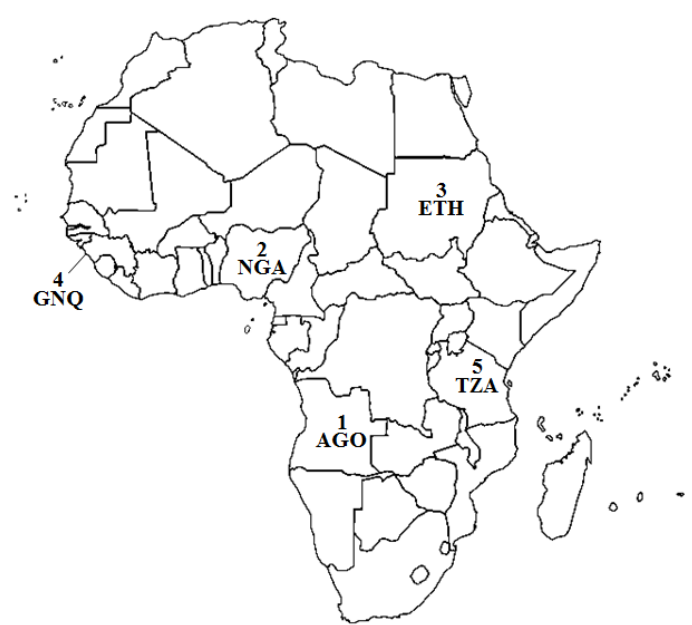

Figure 4-1: Top five countries with highest 'opportunity'

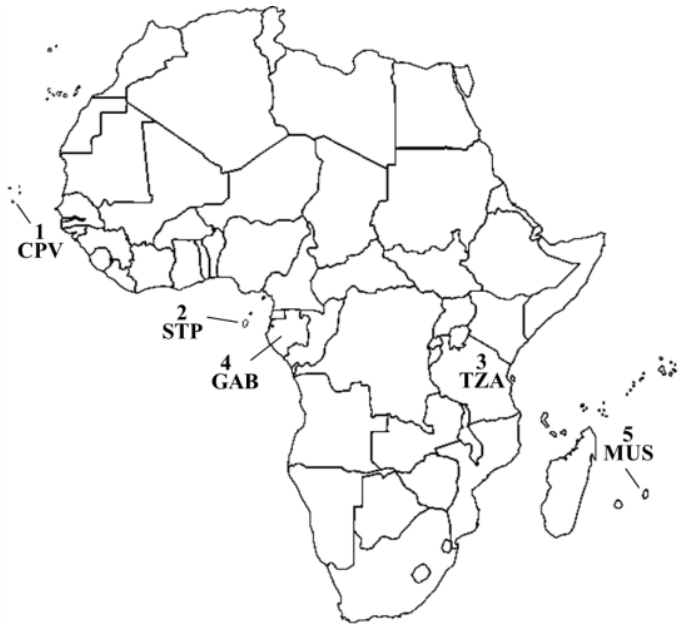

Figure 4-2: Top five countries with lowest 'risk'

Figure 4-3 below is a visualisation of each country, based on its final 'opportunity' and 'risk' ratings. South Africa ('ZAF') is not considered as an investment option, but is included in the graph as a reference data point. An informed decision can now be made to select specific countries for further supply chain network analysis.

This study started by investigating a sample of 43 countries, which is now be reduced to a refined list of two or three countries to consider for further analysis. The reason for reducing the sample size so drastically is to make further analysis feasible within the time and resources that a retailer would typically have to make a strategic decision like the one addressed in the research problem.

The graph can be interpreted by considering the country with the highest 'opportunity' rating and lowest 'risk' rating to be the most attractive. Therefore, a country that is positioned to the bottom right corner of the graph is considered as having a high market attractiveness. From the outputs in Figure 4-3, the country with the highest market attractiveness is Nigeria, with an 'opportunity' rating of 0.51 and a 'risk' rating of 0.44 . Apart from Nigeria, another five countries are identified as being favourable for market expansion, with an 'opportunity' rating greater than 0.42 and a 'risk' rating lower than 0.52. These five countries are Tanzania ('TZA), Angola ('AGO'), Gabon ('GAB'), Ghana ('GHA'), and Ethiopia ('ETH'). The outcomes of the case study conclude that there are six sub-Saharan African countries (from a total sample size of 43) that simultaneously give a high 'opportunity' rating and a low 'risk' rating. Stakeholders may select these six countries for further investigation in the form of a distribution network design (DND) as part of Sub-model 2, which is discussed in the next section.

The case study gives insight into the workings of the AHP sub-model, and the approach is confirmed to be a simple and satisfactory means of modelling the 'opportunity' and 'risk' variables of countries by using expert judgement as data input. 


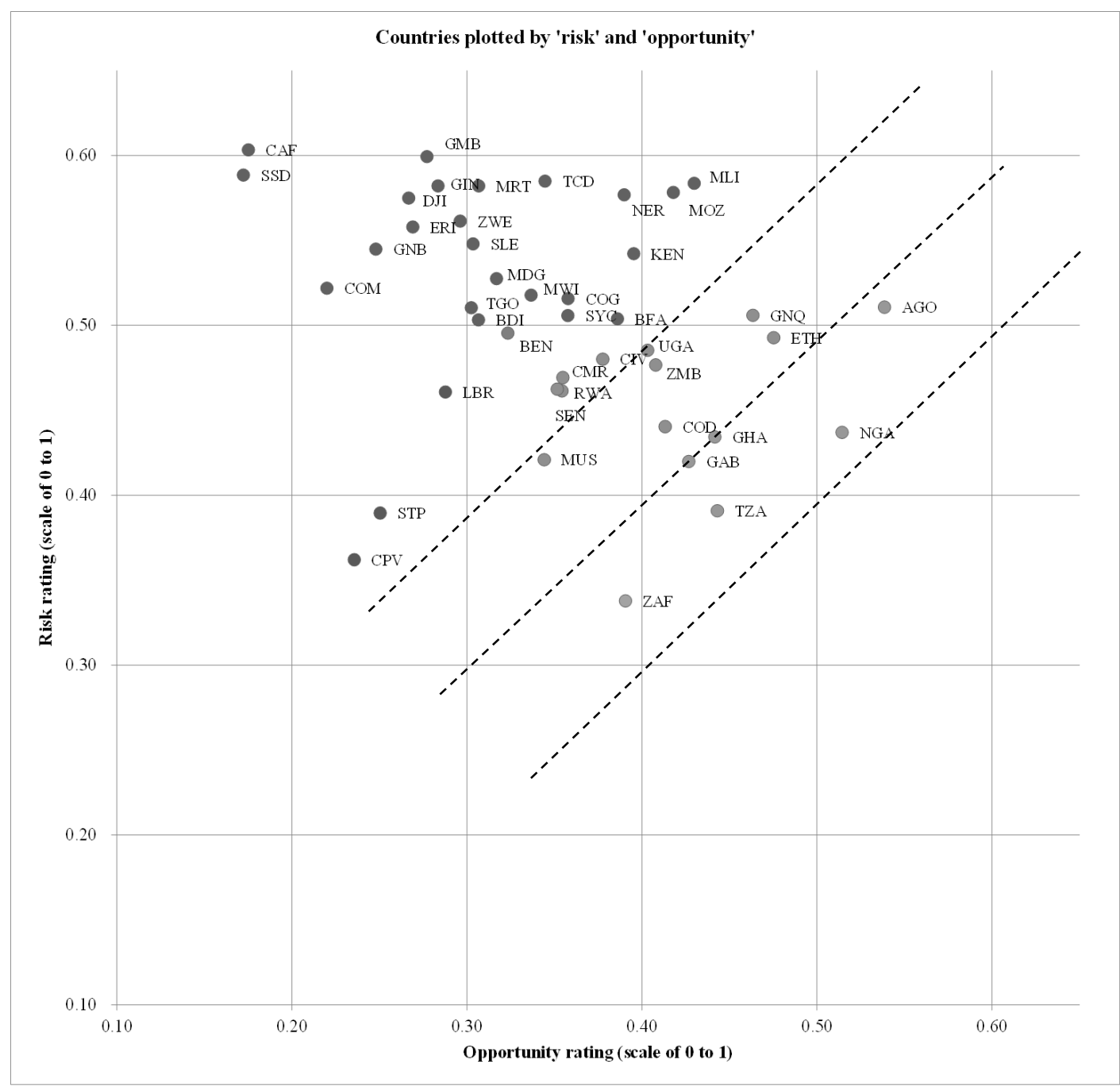

Figure 4-3: Scatter diagram of countries' 'opportunity' and 'risk' ratings

\subsection{Final proposed design of Sub-model 1}

The development of Sub-model 1 can be summarised as a functional specification, as depicted in Figure 4-4 below.

\subsection{Sub-model 2: Distribution network design and the strategic profit model}

This section presents the development of Sub-model 2 through the application of a combination of a distribution network design (DND), Monte Carlo simulation, a strategic profit model (SPM), and benefit-cost analysis. The model will be validated by conducting a sensitivity analysis. Sub-model 2 generates outputs that provide stakeholders with the 'benefit' and 'cost' implications that each strategic expansion scenario would have for the supply chain.

\subsubsection{DND and SPM}

The generated outputs from Sub-model 1 provide us with the best selection of two or three subSaharan African countries to consider for further scenario analysis in the form of a DND. With a focus on the distribution side of the supply chain, the investment decision will take into consideration the number of new stores opened (which is considered as the first indicator of the businesses' unit throughput and potential sales volumes), the various costs of importing goods into that market, storing inventory and processing units in an in-country warehouse, and the transportation cost of distributing products to stores. The DND generates the following outputs: a total estimation of sales; the cost of goods sold; inbound and outbound transport costs; and all other operational costs. By 


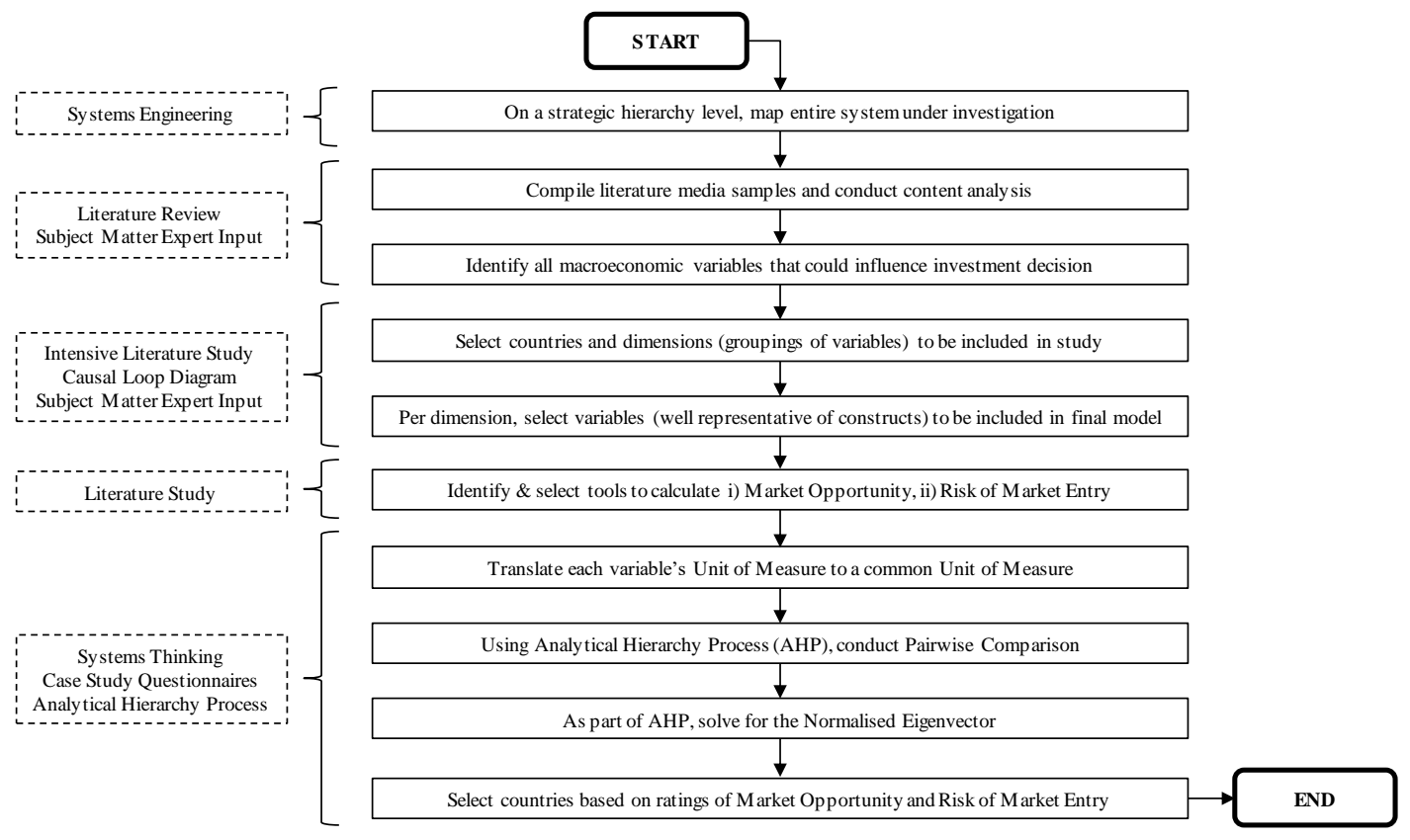

Figure 4-4: The proposed input-output model depicted as a process flow: Sub-model 1

using these variables as inputs into a SPM, important financial ratios can be calculated that give valuable insights into the potential benefits and costs of each scenario.

For conducting a DND, there are considerable constraints in collecting the required data for such simulations. Any retailer would consider this level of data to be highly sensitive information, and collection would be a time-consuming and costly exercise that would fall outside the resources available for this study. In order to illustrate best the final decision-support model, an alternative approach is taken: to simulate the required data points. Instead of using actual data, aliases are estimated by using integrated financial reports of South African retailers that are publicly available. From the financial reports, the following variables are estimated: an average store size; an annual operating profit margin; and the total annual number of units distributed (from which an average annual unit volume per store can be calculated), all of which contribute toward calculating average revenue per store. The inbound and outbound distribution transport costs, as well as the cost of opening new stores and warehouses, vary greatly across countries due to varying levels of infrastructure; but rough estimates can be deduced from data points collected from institutions such as the World Bank. Data points are then converted into a three-value input for the Monte Carlo simulation.

\subsubsection{Monte Carlo simulation}

As there is significant uncertainty in estimating the required inputs, Monte Carlo simulation (and a typical triangular distribution) is used to estimate profit, given uncertain demand and investment costs. Considering the scope and resources available for this study, a Microsoft Excel add-in called Risk Kit [32] is selected to run the Monte Carlo simulations and to compile a sensitivity analysis of the final outputs of Sub-model 2.

To illustrate the workings of the proposed decision-support model, the variables that require simulation under uncertainty are:

- $\quad$ Total estimated sales: calculated by multiplying the estimated unit demand (which would vary for each scenario, depending on the country's potential market size) by the average sell price (which is assumed to remain unchanged across scenarios, but is a controllable variable that could be adjusted to manipulate the net profit margin)

- Cost of goods sold: the direct costs attributable to the production of the goods sold, which in the context of retail distribution would be the cost of supplying the goods from multiple vendors, and is assumed to remain unchanged across scenarios 
- $\quad$ Total inbound and outbound transport costs: both of these variables would vary from country to country, and thus vary across scenarios

- Other operational costs: the value-add costs of the distribution operations of the supply chain

- Estimated current assets: cash and other assets that are expected to be converted to cash within a year

- $\quad$ Total fixed asset investment: the capital investment for opening a new distribution centre and opening about ten new stores as an initial attempt at market-entry.

When using a triangular distribution, three inputs are required for each variable: an optimistic, a most likely, and a pessimistic estimate.

\subsubsection{Validation of Sub-model 2: A sensitivity analysis}

A hypothetical scenario is constructed to simulate a supply chain investment decision for foreign market expansion. For this scenario, it is assumed that stock is 'pushed' to market, and based on experience of the retailer's successes in its host country, unit throughput can be estimated based on an average store size (measured in square meters). Focus is placed on the distribution side of getting stock to market, and the actual marketing attempts (the efforts to increase the sales) are excluded from the scope of this study.

Figure 4-5 shows the final hypothetical inputs used to illustrate and test the input-output model. For the example reflected in Figure 4-5, Monte Carlo simulation is run for 1000 iterations. The outputs generated by the Monte Carlo calculations then serve as the input to the strategic profit model, which is discussed next. A sensitivity analysis is conducted to confirm the logic of the strategic profit model, based on the Monte Carlo simulated data points.

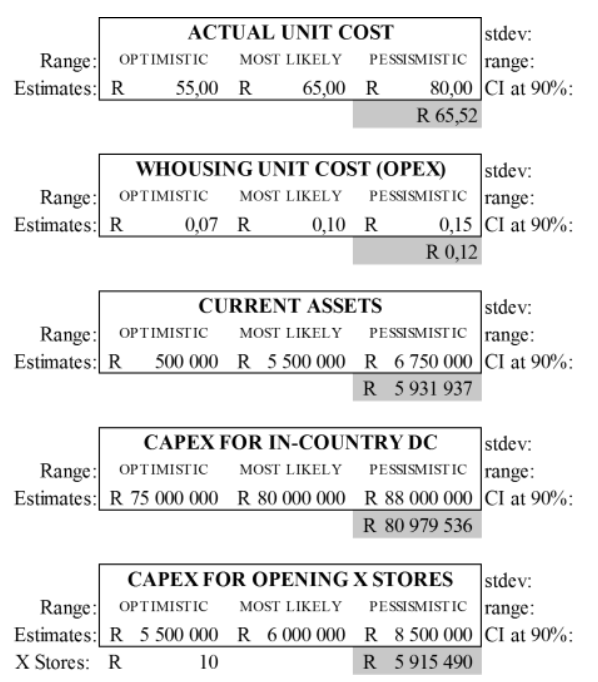

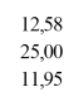

Figure 4-5: Three inputs per variable for triangular distribution, and Monte Carlo outputs in highlighted cells

The simulation detail and inner workings of Sub-model 2 will receive less focus in this article than those of Sub-model 1. It is necessary, however, to include some form of review and discussion, as the aim of this research is to take a holistic approach to complex decision modelling. The mathematics of the supply chain network simulation falls outside the scope of the strategic inputoutput model. Due to real data points of retailers being unavailable for this study, a 'best guess' is used with the assistance of a Monte Carlo simulation.

Investment decisions contain many uncertain variables, and it is critical that stakeholders understand both the benefit and the cost impact of the expansion decision, given the uncertainty. The first step in addressing each variable and its impact on the profit model is to identify which model inputs are controllable and which are uncontrollable. In the case of this research study, the unit throughput and sell price are considered to be 'controllable'. Even though sales are largely considered to be an uncontrollable variable, a retailer can take a stock distribution 'push' approach by initially distributing a planned number of units to a store. By keeping the figures for estimated sales and COGS static across each of the different scenarios, these two variables would be regarded 
as known and controllable variables, whereas the variables for costs (inbound and outbound transportation, other operation costs, fixed and current assets) are the uncontrollable variables in the model. Sensitivity analysis is conducted by using the Risk Kit Microsoft Excel add-in [32].

\subsubsection{Strategic profit model for financial ratios}

By using the outputs from the Monte Carlo simulation exercise, the strategic profit model is populated to calculate the final benefits and costs for each scenario under investigation.

The ratios of net profit margin and return on assets are good measures of the benefits of the expansion decision, with the total operating cost and total assets being a fitting reflection of the cost of the expansion decision. For the hypothetical inputs used to test this model, the various ratios are calculated by using the format of a strategic profit model. An example of the outputs is displayed in Table 4-8, which can be calculated for each scenario simulated during the DND. The cost and benefit outputs are now scrutinised and compared with one another to make an informed investment decision. In reality, the total estimated unit demand of a foreign market could be calculated for each country by means of third-party marketing research. (This is not covered in the scope of this study, but is still strongly recommended for a holistic decision-making approach.)

Table 4-8: Financial ratios

\begin{tabular}{|c|c|}
\hline & SAMPLE \\
\hline *Total unit demand & 2421660 \\
\hline $\begin{array}{l}\text { *Sell price per unit } \\
=\end{array}$ & R 85,57 \\
\hline sales & R 207219945 \\
\hline *cost of goods sold & R 158668878 \\
\hline GROSS MARGIN & R 48551066 \\
\hline *outbound transport cost & R 10981525 \\
\hline *inbound transport cost & R 13840563 \\
\hline *other operating costs & R 245830 \\
\hline TOTAL OPERATING COST & R 25067918 \\
\hline NET INCOME & R 23483148 \\
\hline NET PROFIT MARGIN & $11 \%$ \\
\hline *dc capex & R 87043228 \\
\hline *opening stores capex & R 7034133 \\
\hline fixed assets & R 94077361 \\
\hline *current assets & R 4465439 \\
\hline TOTAL ASSETS & R 98542800 \\
\hline ASSET TURNOVER & $210 \%$ \\
\hline RETURN ON ASSETS & $24 \%$ \\
\hline
\end{tabular}

For the purpose of illustration, an estimate calculation is done by assuming that the retailer would open ten average-sized new retail stores in an urban market environment. The total unit demand is multiplied by the average estimated 'sell price per unit' to give an approximation of the total potential sales across each of the selected markets. An estimate for 'sell price' can be deduced by calculating the current average sell price of similar retail commodities in the South African market. Furthermore, the cost of goods sold is deducted from the total sales to calculate the gross margin, which is a valuable indicator of the financial benefit (conveyed on a 'per unit' level) that a retailer could realise when entering a market.

Two variables that are expected to differ greatly between various countries are the inbound and outbound transportation costs. Developing African countries have varying levels of infrastructure development, which is directly correlated with the cost of distribution. Transportation costs and other operating costs are added together to calculate the total operating cost. Hereafter, the net income can be calculated by subtracting the total operating cost from the gross margin. Net profit margin is now calculated as a percentage value, by dividing the net income by the total sales. 
The total value of fixed assets (consisting of the capital investment required to open a new distribution centre and ten new average-sized retail stores) is added to the estimated current assets, to calculate the value of the total assets of the business. By dividing the estimated total assets figure by the total sales, a ratio is calculated that reflects the asset turnover. This ratio can often be used as an indicator of the efficiency with which a company is deploying its assets in generating revenue.

Finally, the return on assets is calculated as the final indicator of investment benefit. This is calculated by dividing the net income by the total assets.

\subsubsection{Benefit-cost analysis}

A simple benefit-cost analysis can be conducted by combining what-if analysis with the strategic profit model outputs. Newnan et al. [17] explain that the benefit-cost analysis is based on the concept of total benefits (B) minus total cost (C) being greater than or equal to zero (Equation 1), otherwise stated as the benefits divided by the cost being greater or equal to one (Equation 2 ).

$$
\begin{array}{cc}
\text { Equation 1 } & B-C \geq 0 \\
\text { Equation 2 } & \frac{B}{C} \geq 1
\end{array}
$$

In a scenario where both benefits and costs are variable inputs, an incremental benefit-cost ratio analysis can be conducted; the alternative with the highest ratio will then be considered to be the most attractive option. In the hypothetical example in Figure 4-6 below, for each increment of investment where Equation 2 holds as being true, the investment is considered to be an attractive alternative to consider for further investigation.

In the example, alternative $C$ would thus be the most desirable for investment. Outputs from the Monte Carlo simulation and sensitivity analysis are included in Appendix A.

BENEFIT-COST RATIO ANALYSIS

GROSS MARGIN

TOTAL OPS COST

$\mathrm{B} / \mathrm{C}$

DELTA B/C

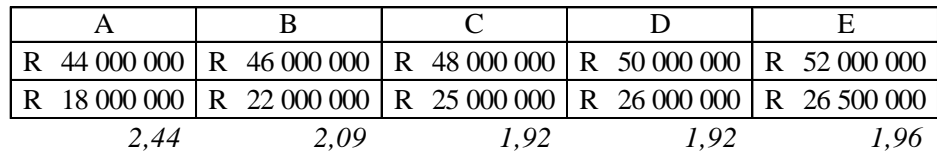

\begin{tabular}{|r|r|r|r|}
\hline \multicolumn{1}{|c|}{ B-A } & \multicolumn{1}{|c|}{ C-B } & \multicolumn{1}{|c|}{ D-C } & \multicolumn{1}{c|}{ E-D } \\
\hline 0,50 & 0,67 & 2,00 & 4,00 \\
\hline
\end{tabular}

Figure 4-6: Example of a typical benefit-cost ratio analysis

\subsection{Final proposed design of Sub-model 2}

The development of Sub-model 1 can be summarised as a functional specification, as depicted in Figure 4-7 below.

\subsection{Final proposed decision-support model}

The two sub-models are now combined to present a holistic decision-support model that is simple enough for stakeholders to use in making decisions during foreign market expansion efforts. The first sub-model is primarily of a qualitative nature, as it considers macro-economic variables and indices, while the second sub-model is considered to be a quantitative business case (considering the fields of supply chain network and company financials in combination) for determining whether or not foreign market expansion would be financially feasible. Keep in mind that the expansion decision can be made across three different levels: strategic, tactical, and operational; but this study focuses on the strategic level only, with the tactical and operational variables falling outside its scope. The final proposed decision-support model is depicted in Figure 4-8 below.

The four main constructs evolving from the proposed model ('opportunity', 'risk', 'benefit', and 'cost') can now be compared against one another for a holistic consideration of countries during the investment decision-making process. 


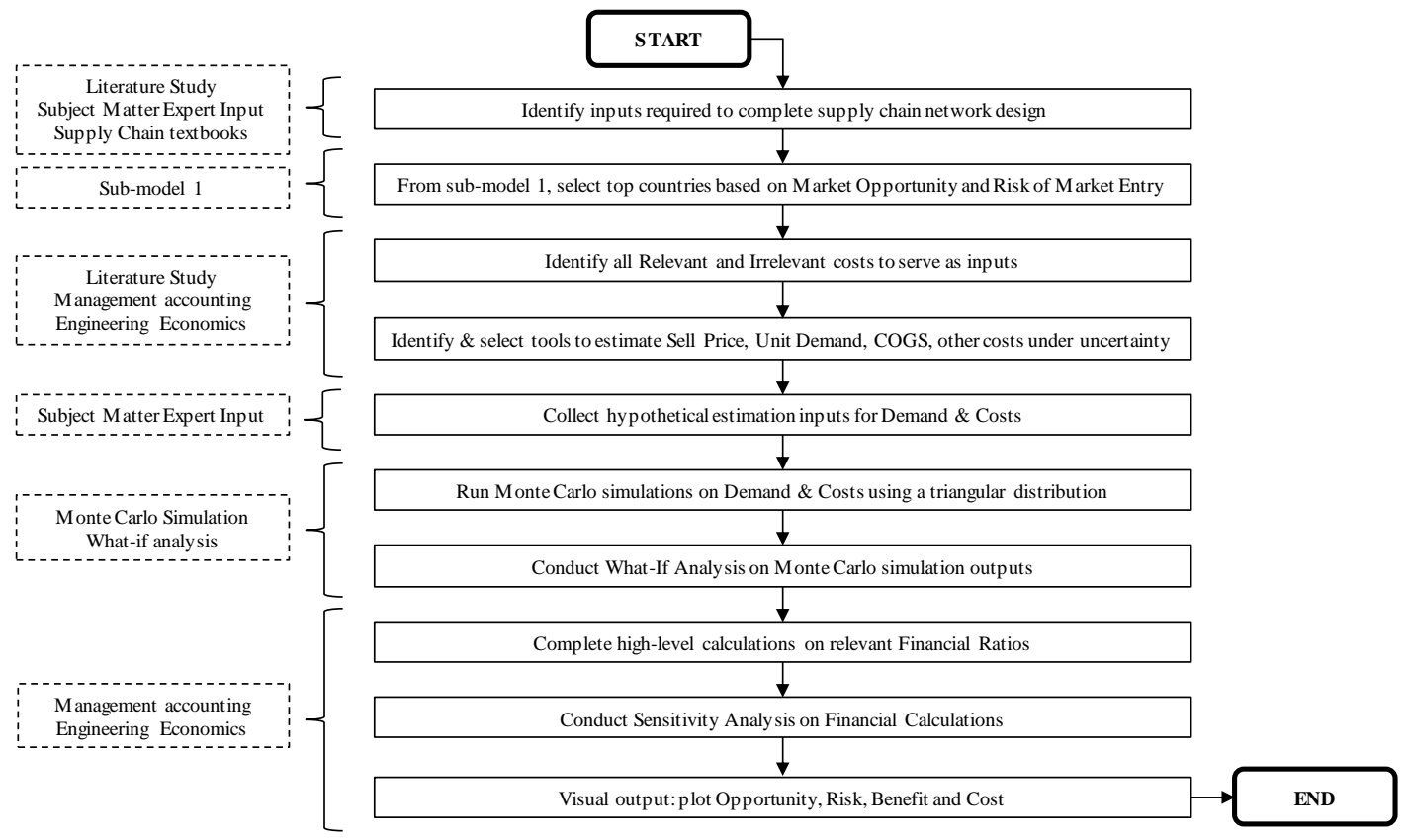

Figure 4-7: The proposed input-output model depicted as a process flow: Sub-model 2

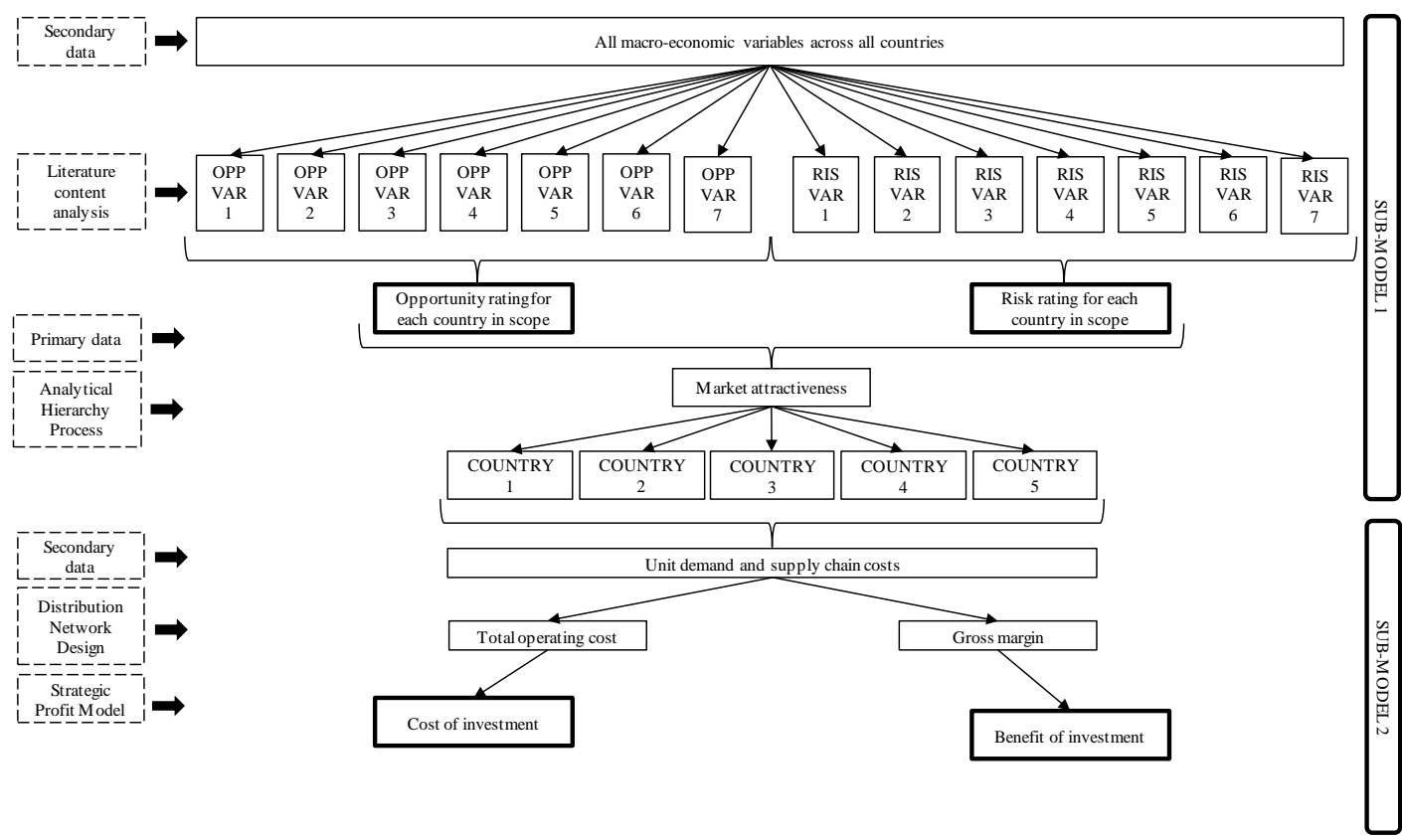

Figure 4-8: The final proposed decision-support model

\section{CONCLUSION}

Macro-economic data show that many African countries have experienced an improvement in factors such as GDP, labour productivity, democracy, infrastructure, foreign direct investment, and job creation, and a decline in foreign debt and inflation, over the past 10 years. Combined with an increase in urbanisation and an expanding middle class (with higher disposable income), many African countries are now in a position to attract potential foreign investors, especially in the consumer products and retail sector. 
Foreign market expansion is a business decision that requires a structured analytical framework to assist in the decision-making efforts of potential foreign investors. Models should be synthesised to assess and prioritise which market, country, or region to enter next; and what the opportunities and risks of such a move will be. A decision on foreign market expansion cannot be based solely on the variables of market opportunity and risk involved in the expansion process; the potential monetary benefits and costs need also be quantified and taken into consideration.

The article presents a strategic decision-support model for a South African retailer that is looking to expand its business into markets in sub-Saharan Africa by taking a holistic approach that covers various disciplines, including supply chain management, economics of development, and financial management. The study identifies the qualitative and quantitative variables that should be considered during foreign market expansion, and that are successfully translated into comparable values for the goal of selecting foreign markets with the highest investment potential. The application of systems thinking is vital for taking a holistic approach during the complex decisionmaking process. This approach leads to the combination of a list of tools and techniques that are most apt for building a decision-support model, including spreadsheet applications, the analytical hierarchy process, a supply chain distribution network design, Monte Carlo simulation, sensitivity analysis, what-if analysis, and the strategic profit model. Each of the tools is integrated into the final proposed decision-support model, providing stakeholders with a simplified approach to a complex investment decision.

Further research can be conducted into applying this model concept to various industries. As the opportunity and risk of a market are highly dependent on the view and context of the stakeholder making the expansion decision, it can be expected that variable outcomes would look different for an industry other than retail.

\section{REFERENCES}

[1] Marshall, T. 2015. Prisoners of geography: Ten maps that tell you everything you need to know about global politics. London: Elliot and Thompson.

[2] Gillis, M., Perkins, D.H., Roemer, M. \& Snodgrass, D.R. 2006. Economics of development. New York: WW Norton \& Company, Inc.

[3] Levi, D.S., Kaminsky, P. \& Levi, E.S. 2003. Designing and managing the supply chain: Concepts, strategies, and case studies. United States: McGraw-Hill.

[4] Gbadamosi, A. 2013. Consumer involvement and marketing in Africa: Some directions for future research. International Journal of Consumer Studies, 37(2):234-242.

[5] Ernst \& Young. 2014. Converting Africa's potential into profit: The opportunity for consumer products companies.

[6] ATKearney. 2015. The 2015 African Retail Development Index: Retail in Africa: Still the next big thing.

[7] PwC. 2012. PWC's cities of opportunity: Through a retail and consumer lens.

[8] Brouthers, K.D. 2013. A retrospective on: Institutional, cultural and transaction cost influences on entry mode choice and performance. Journal of International Business Studies, 44(1):14-22.

[9] Khanna, T. \& Palepu, K. 2013. Winning in emerging markets: A road map for strategy and execution. Harvard: Harvard Business Press.

[10] Akbar, Y.H., Bortoluzzi, G. \& Tracogna, A. 2014. Beyond entry mode-SME escalation in emerging markets: A conceptual framework. Journal for International Business and Entrepreneurship Development, 7(4):326340.

[11] Ahsan, M. \& Musteen, M. 2011. Multinational enterprises' entry mode strategies and uncertainty: A review and extension. International Journal of Management Reviews, 13(4):376-392.

[12] Frazelle, E. 2002. Supply chain strategy: The logistics of supply chain management. United States: McGraw Hill.

[13] Coyle, J.J., Gibson, B.J., Langley, C.J. \& Novack, R.A. 2013. Managing supply chains: A logistics approach. United States: South-Western Cengage Learning.

[14] Kossiakoff, A., Sweet, W.N., Seymour, S.J. \& Biemer, S.M. 2011. Systems engineering principles and practice. Vol. 83. United States: John Wiley \& Sons.

[15] Forrester, J.W. 1994. System dynamics, systems thinking, and soft OR. System Dynamics Review, 10(23):245-256.

[16] Jackson, M.C. 2003. Systems thinking: Creative holism for managers. Chichester: John Wiley and Sons Ltd.

[17] Newnan, D.G., Eschenbach, T. \& Lavelle, J.P. 2004. Engineering economic analysis, Vol. 2. New York: Oxford University Press.

[18] World Economic Forum. 2017. The Global Competitiveness Report. [Online]. Available: https://www.weforum.org/reports/the-global-competitiveness-report-2017-2018 [Accessed April 2017].

[19] Mo Ibrahim Foundation. 2016. Ibrahim Index of African Governance. [Online]. Available: http://mo.ibrahim.foundation/iiag/ [Accessed July 2016]. 
[20] Heritage Foundation. 2017. Index of Economic Freedom. [Online]. Available: http:/ /www.heritage.org/index/ [Accessed March 2017].

[21] PRS Group. 2017. International Country Risk Guide. [Online]. Available: http: / /epub.prsgroup.com/products/international-country-risk-guide-icrg [Accessed February 2017].

[22] Transparency International. 2016. Corruption Perceptions Index. [Online]. Available: https://www.transparency.org/research/cpi [Accessed November 2016].

[23] World Bank. 2016. Logistics Performance Index. [Online]. Available: https://lpi.worldbank.org/ [Accessed October 2016].

[24] World Bank. 2016. The World Bank: Doing business. [Online]. Available: http://www.doingbusiness.org/ [Accessed November 2016].

[25] Llamasoft. 2017. LogicNet Plus ${ }^{\circledR}$ XE. [Online]. Available: https: //www.llamasoft.com/products/design/logictools [Accessed April 2017].

[26] Saaty, T.L. 2008. Decision making with the analytic hierarchy process. International Journal of Services Sciences, 1(1):83-98.

[27] Vargas, L.G. 1990. An overview of the analytic hierarchy process and its applications. European Journal of Operational Research, 48(1):2-8.

[28] Goepel, K.D. 2013. Implementing the analytic hierarchy process as a standard method for multi-criteria decision making in corporate enterprises - A new AHP excel template with multiple inputs. In Proceedings of the International Symposium on the Analytic Hierarchy Process, 2013, 1-10.

[29] Geoffrion, A.M. \& Van Roy, T.J. 1979. Caution: Common sense planning methods can be hazardous to your corporate health. Sloan Management Review, 20(4):31-42.

[30] Savage, S.L. 2003. Decision making with insight (with Insight.xla 2.0 and CD-ROM). United States: Cengage Learning, Inc.

[31] Grable, J.E. \& Lytton, R.H. 2001. Assessing the concurrent validity of the SCF risk tolerance question. Journal of Financial Counseling and Planning, 12(2):43.

[32] Wehrspohn. 2017. Wehrspohn risk management. [Online]. Available: http://www.wehrspohn.info/en/products/risk-kit.html [Accessed June 2017]. 


\begin{tabular}{|c|c|c|c|c|c|}
\hline \multirow{3}{*}{$\begin{array}{r}\text { Range: } \\
\text { Estimates }\end{array}$} & \multicolumn{3}{|c|}{ UNIT DEMAND (market size): } & \multirow{2}{*}{$\begin{array}{l}\text { stdev: } \\
\text { range: }\end{array}$} & \multirow{2}{*}{$\begin{array}{r}529150 \\
1000000\end{array}$} \\
\hline & OPTIMISTIC & MOST LIKELY & PESSISMISTIC & & \\
\hline & 3000000 & 2200000 & 2000000 & \multirow[t]{2}{*}{ CI at $90 \%$ : } & \multirow[t]{2}{*}{502511} \\
\hline \multirow[t]{2}{*}{ X Stores: } & \multicolumn{2}{|l|}{10} & 2426495 & & \\
\hline & \multicolumn{3}{|c|}{ SELL PRICE PER UNIT } & \multirow{4}{*}{$\begin{array}{l}\text { stdev: } \\
\text { range: } \\
\text { CI at } 90 \% \text { : }\end{array}$} & \multirow{4}{*}{$\begin{array}{l}20,82 \\
40,00 \\
19,77\end{array}$} \\
\hline Range: & OPTIMISTIC & MOST LIKELY & PESSISMISTIC & & \\
\hline \multirow[t]{3}{*}{ Estimates: } & 120,00 & 90,00 & 80,00 & & \\
\hline & \multicolumn{3}{|r|}{ R 93,34 } & & \\
\hline & \multicolumn{3}{|c|}{ OUTBOUND TRANS UNIT COST } & stdev: & 1,00 \\
\hline Range: & OPTIMISTIC & MOST LIKELY & PESSISMISTIC & range: & 2,00 \\
\hline \multirow[t]{3}{*}{ Estimates: } & 3,50 & 4,50 & 5,50 & \multirow{2}{*}{$\mathrm{CI}$ at $90 \%$ : } & \multirow[t]{2}{*}{0,95} \\
\hline & \multicolumn{3}{|r|}{$\mathrm{R} 3,87$} & & \\
\hline & \multicolumn{3}{|c|}{ INBOUND / IMPORT UNIT COST } & stdev: & 2,00 \\
\hline & OPTIMISTIC & MOST LIKELY & PESSISMISTIC & range: & 4,00 \\
\hline Estimates: & 3,00 & 5,00 & 7,00 & CI at $90 \%$ : & 1,90 \\
\hline & & & R 5,07 & & \\
\hline & ACT & UAL UNIT C & OST & stdev: & 12,58 \\
\hline Range: & OPTIMISTIC & MOST LIKELY & PESSISMISTIC & range: & 25,00 \\
\hline Estimates: & 55,00 & 65,00 & 80,00 & $\mathrm{CI}$ at $90 \%$ : & 11,95 \\
\hline & & & R 65,52 & & \\
\hline & WHOUSII & NG UNIT COS & T (OPEX) & stdev: & 0,04 \\
\hline Range: & OPTIMISTIC & MOST LIKELY & PESSISMISTIC & range: & 0,08 \\
\hline Estimates: & 0,07 & 0,10 & 0,15 & CI at $90 \%$ : & 0,04 \\
\hline & & & R 0,12 & & \\
\hline & $\mathbf{C U}$ & RRENT ASSE & TS & stdev: & 3307189 \\
\hline Range: & OPTIMISTIC & MOST LIKELY & PESSISMISTIC & range: & 6250000 \\
\hline Estimates: & 500000 & R 5500000 & R 6750000 & $\mathrm{CI}$ at $90 \%$ : & 3140694 \\
\hline & & & R 5931937 & & \\
\hline & CAPEX F & OR IN-COUI & TRY DC & stdev: & 6557439 \\
\hline Range: & OPTIMISTIC & MOST LIKELY & PESSISMISTIC & range: & 13000000 \\
\hline Estimates: & R 75000000 & R 80000000 & R 88000000 & $\mathrm{CI}$ at $90 \%$ : & 6227315 \\
\hline & & & R 80979536 & & \\
\hline & CAPEX FO & R OPENING & X STORES & stdev: & 1607275 \\
\hline Range: & OPT IMISTIC & MOST LIKELY & PESSISMIST IC & range: & 3000000 \\
\hline Estimates: & R 5500000 & R 6000000 & R 8500000 & $\mathrm{CI}$ at $90 \%$ : & 1526360 \\
\hline X Stores: & 10 & & R 5915490 & & \\
\hline
\end{tabular}

Figure A-1: Three inputs selected for each variable and the outputs of the Monte Carlo simulation in orange 


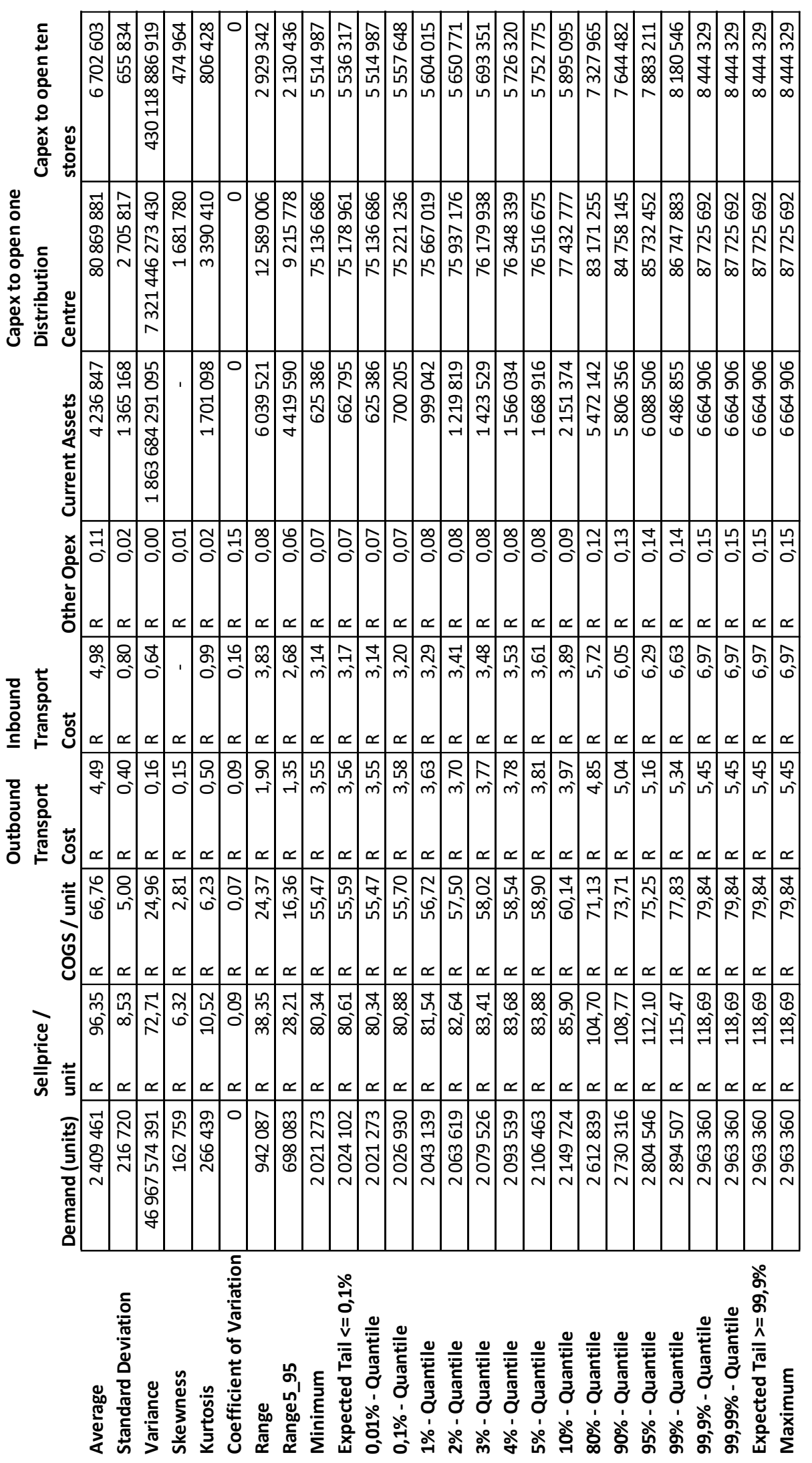

Figure A-2: Final iteration of Monte Carlo simulation (with 1000 runs) 
WHAT-IF ON SALES: unit demand vs sell price

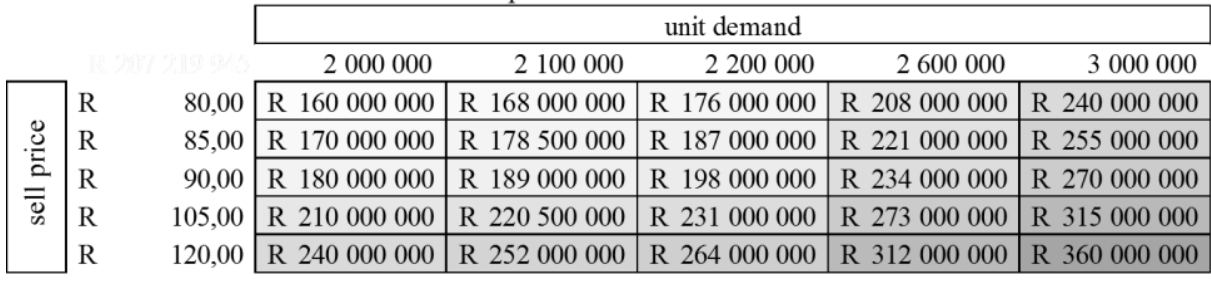

WHAT-IF ON COGS: cogs per units vs unit demand

\begin{tabular}{|c|c|c|c|c|c|c|}
\hline & \multicolumn{5}{|c|}{ cogs/unit } \\
\hline & & 55 & 60 & 65 & 73 & 80 \\
\hline \multirow{5}{*}{ 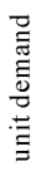 } & 2000000 & 110000000 & 120000000 & 130000000 & 145000000 & 160000000 \\
\hline & 2100000 & 115500000 & 126000000 & 136500000 & 152250000 & 168000000 \\
\hline & 2200000 & 121000000 & 132000000 & 143000000 & 159500000 & 176000000 \\
\hline & 2600000 & 143000000 & 156000000 & 169000000 & 188500000 & 208000000 \\
\hline & 3000000 & 165000000 & 180000000 & 195000000 & 217500000 & 240000000 \\
\hline
\end{tabular}

WHAT-IF ON GROSS MARGIN: sales vs cogs

\begin{tabular}{|r|r|r|r|r|r|}
\hline \multicolumn{5}{|c|}{ sales } \\
\hline R 160000000 & R 210000000 & R 260000000 & R 310000000 & R 360000000 \\
\hline & 50000000 & 100000000 & 150000000 & 200000000 & 250000000 \\
\hline 17500000 & 67500000 & 117500000 & 167500000 & 217500000 \\
\hline$-\quad 15000000$ & 35000000 & 85000000 & 135000000 & 185000000 \\
\hline$-\quad 47500000$ & 2500000 & 52500000 & 102500000 & 152500000 \\
\hline$-\quad 80000000$ & - & 30000000 & 20000000 & 70000000 & 120000000 \\
\hline
\end{tabular}

Results from the sensitivity analysis conducted on the Monte Carlo variables below:
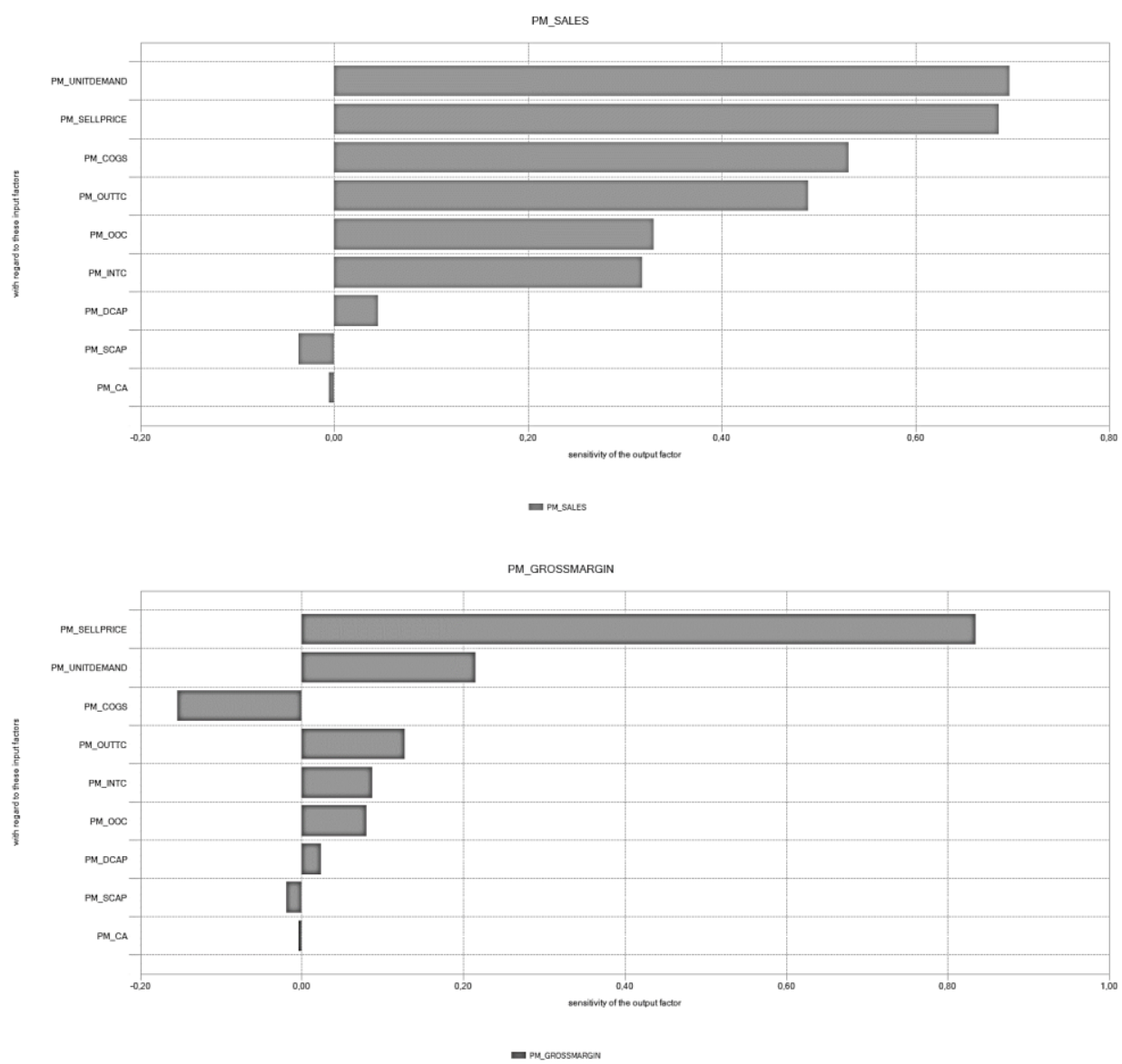
Impact of variables on the net income and profit margin:

WHAT-IF ON TOTAL OPERATING COST: inbound \& outbound transport costs vs unit demand

\begin{tabular}{|c|c|c|c|c|c|c|c|c|c|c|c|}
\hline & & \multicolumn{10}{|c|}{ inbound \& outbound transport cost per unit } \\
\hline & & $\mathrm{R}$ & 6,50 & $\mathrm{R}$ & 8,00 & $\mathrm{R}$ & 9,50 & $\mathrm{R}$ & 11,00 & $\mathrm{R}$ & 12,50 \\
\hline \multirow{5}{*}{ 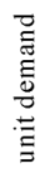 } & 2000000 & $\mathrm{R}$ & 13245830 & $\mathrm{R}$ & 16245830 & $\mathrm{R}$ & 19245830 & $\mathrm{R}$ & 22245830 & $\mathrm{R}$ & 25245830 \\
\hline & 2100000 & $\mathrm{R}$ & 13895830 & $\mathrm{R}$ & 17045830 & $\mathrm{R}$ & 20195830 & $\mathrm{R}$ & 23345830 & $\mathrm{R}$ & 26495830 \\
\hline & 2200000 & $\mathrm{R}$ & 14545830 & $\mathrm{R}$ & 17845830 & $\mathrm{R}$ & 21145830 & $\mathrm{R}$ & 24445830 & $\mathrm{R}$ & 27745830 \\
\hline & 2600000 & $\mathrm{R}$ & 17145830 & $\mathrm{R}$ & 21045830 & $\mathrm{R}$ & 24945830 & $\mathrm{R}$ & 28845830 & $\mathrm{R}$ & 32745830 \\
\hline & 3000000 & $\mathrm{R}$ & 19745830 & $\mathrm{R}$ & 24245830 & $\mathrm{R}$ & 28745830 & $\mathrm{R}$ & 33245830 & $\mathrm{R}$ & 37745830 \\
\hline
\end{tabular}

WHAT-IF ON NET INCOME: gross margin vs total operating cost

\begin{tabular}{|c|c|c|c|c|c|c|c|c|c|}
\hline \multirow{2}{*}{\multicolumn{2}{|c|}{ 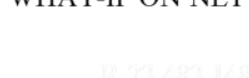 }} & \multicolumn{8}{|c|}{ gross margin } \\
\hline & & 2500000 & & 26875000 & & 51250000 & & 75625000 & 100000000 \\
\hline \multirow{5}{*}{$\begin{array}{l}\tilde{6} \\
0 \\
0 \\
0 \\
0 \\
\frac{\pi}{0}\end{array}$} & 13000000 & $\mathrm{R}-10500000$ & $\mathrm{R}$ & 13875000 & $\mathrm{R}$ & 38250000 & $\mathrm{R}$ & 62625000 & R 87000000 \\
\hline & 19250000 & $\mathrm{R}-16750000$ & $\mathrm{R}$ & 7625000 & $\mathrm{R}$ & 32000000 & $\mathrm{R}$ & 56375000 & R 80750000 \\
\hline & 25500000 & $\mathrm{R}-23000000$ & $\mathrm{R}$ & 1375000 & $\mathrm{R}$ & 25750000 & $\mathrm{R}$ & 50125000 & R 74500000 \\
\hline & 31750000 & R -29250000 & $\mathrm{R}$ & -4875000 & $\mathrm{R}$ & 19500000 & $\mathrm{R}$ & 43875000 & R 68250000 \\
\hline & 38000000 & $R-35500000$ & $\mathrm{R}$ & -11125000 & $\mathrm{R}$ & 13250000 & $\mathrm{R}$ & 37625000 & R 62000000 \\
\hline
\end{tabular}

WHAT-IF ON NET PROFIT MARGIN: sales vs net income

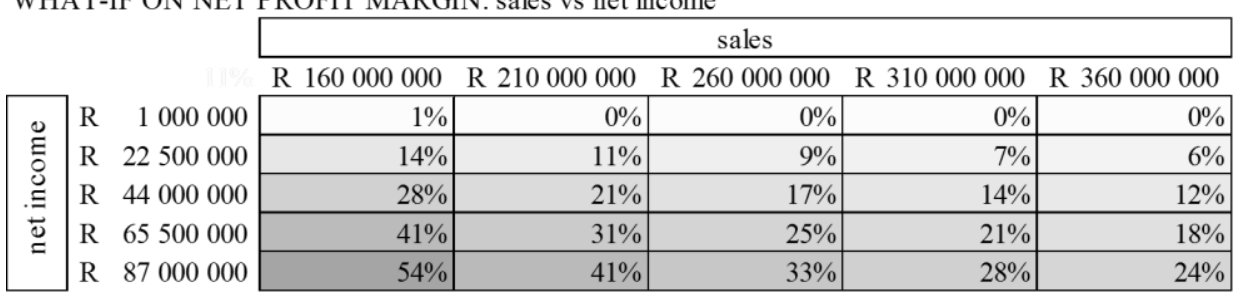

For the purposes of this investigation, gross margin is considered to be the benefit of the market expansion decision, with the total operational cost considered as the final cost parameter.

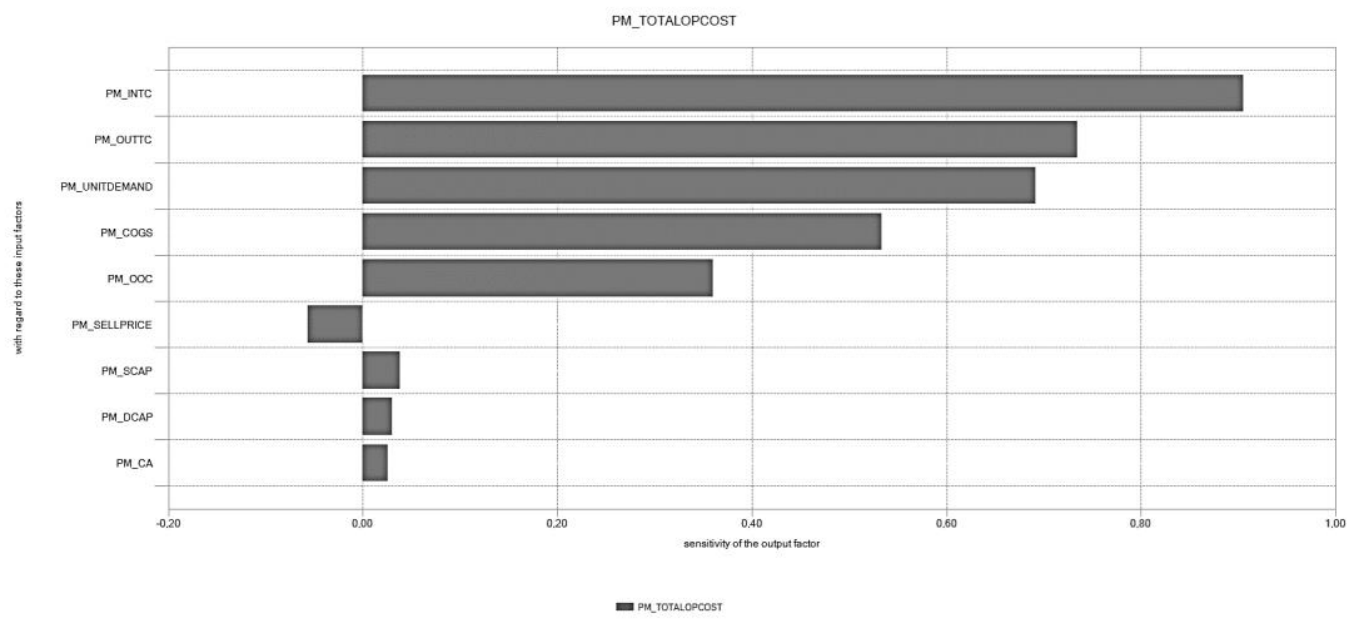


PM_NETINCOME

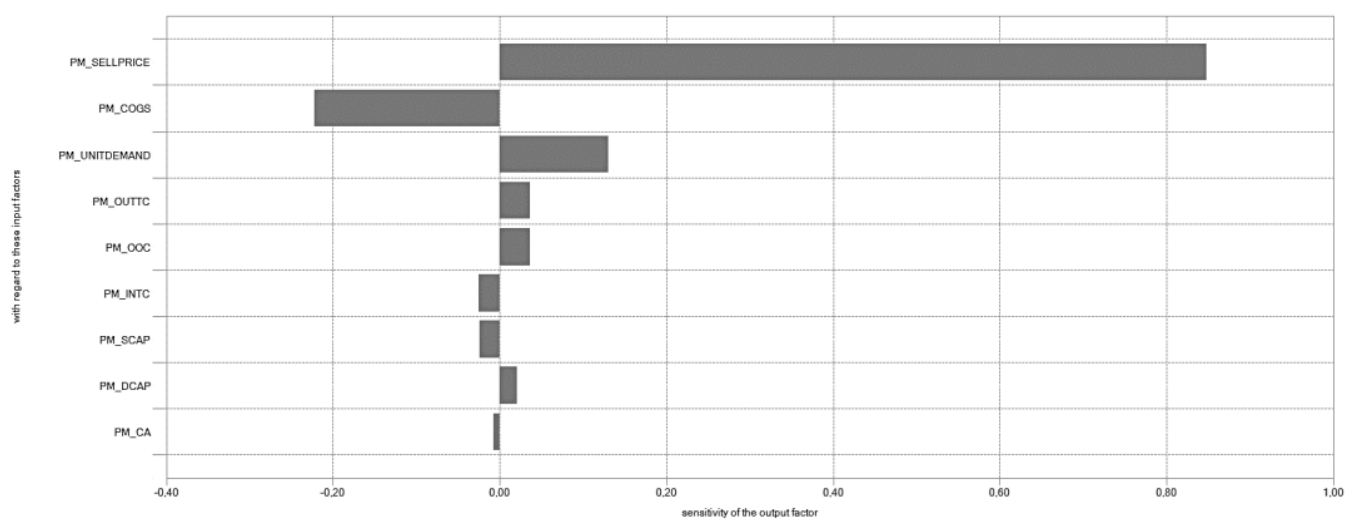

- pugenncone

PM_NETPROFITMARGIN

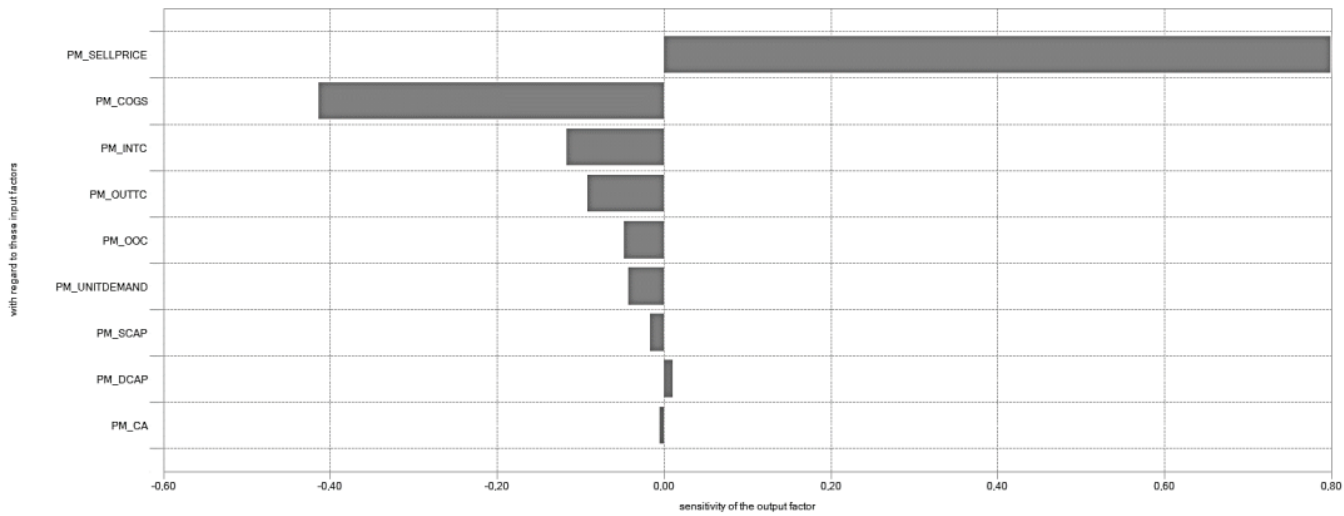

D PM NetPaoftmaagin

WHAT-IF ON RETURN ON ASSETS: total assests vs net income

total assets

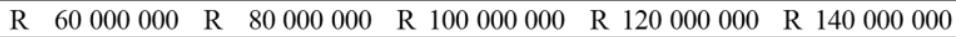

\begin{tabular}{|c|c|c|c|c|c|c|}
\hline & \multirow{5}{*}{ 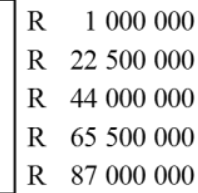 } & $2 \%$ & $1 \%$ & $1 \%$ & $1 \%$ & $1 \%$ \\
\hline & & $38 \%$ & $28 \%$ & $23 \%$ & $19 \%$ & $16 \%$ \\
\hline & & $73 \%$ & $55 \%$ & $44 \%$ & $37 \%$ & $31 \%$ \\
\hline & & $109 \%$ & $82 \%$ & $66 \%$ & $55 \%$ & $47 \%$ \\
\hline & & $145 \%$ & $109 \%$ & $87 \%$ & $73 \%$ & $62 \%$ \\
\hline
\end{tabular}

PM_TOTALASSET

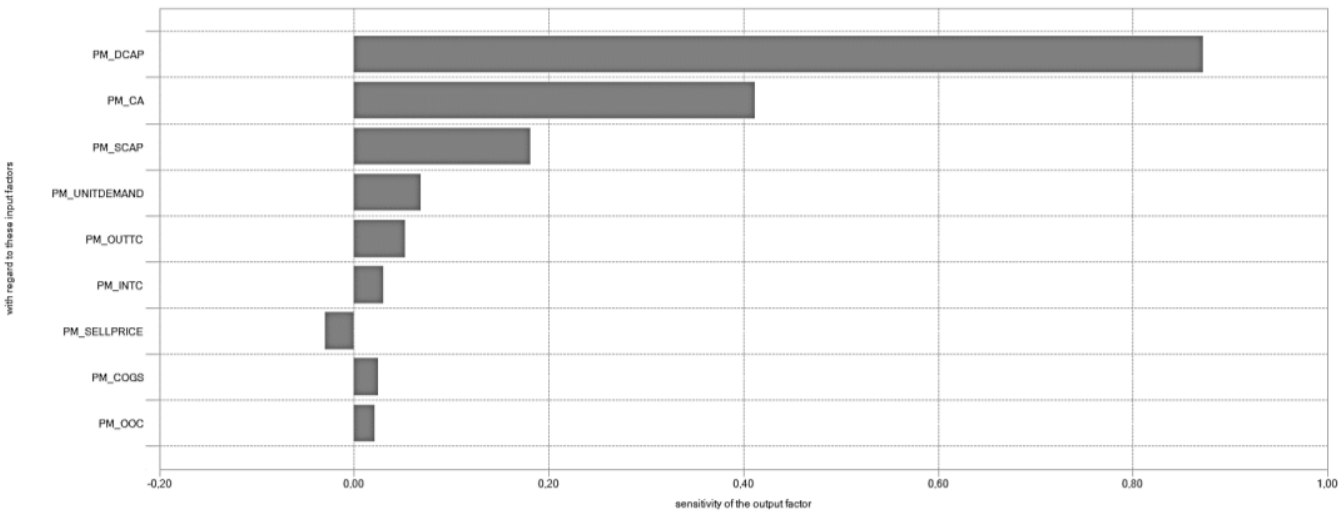



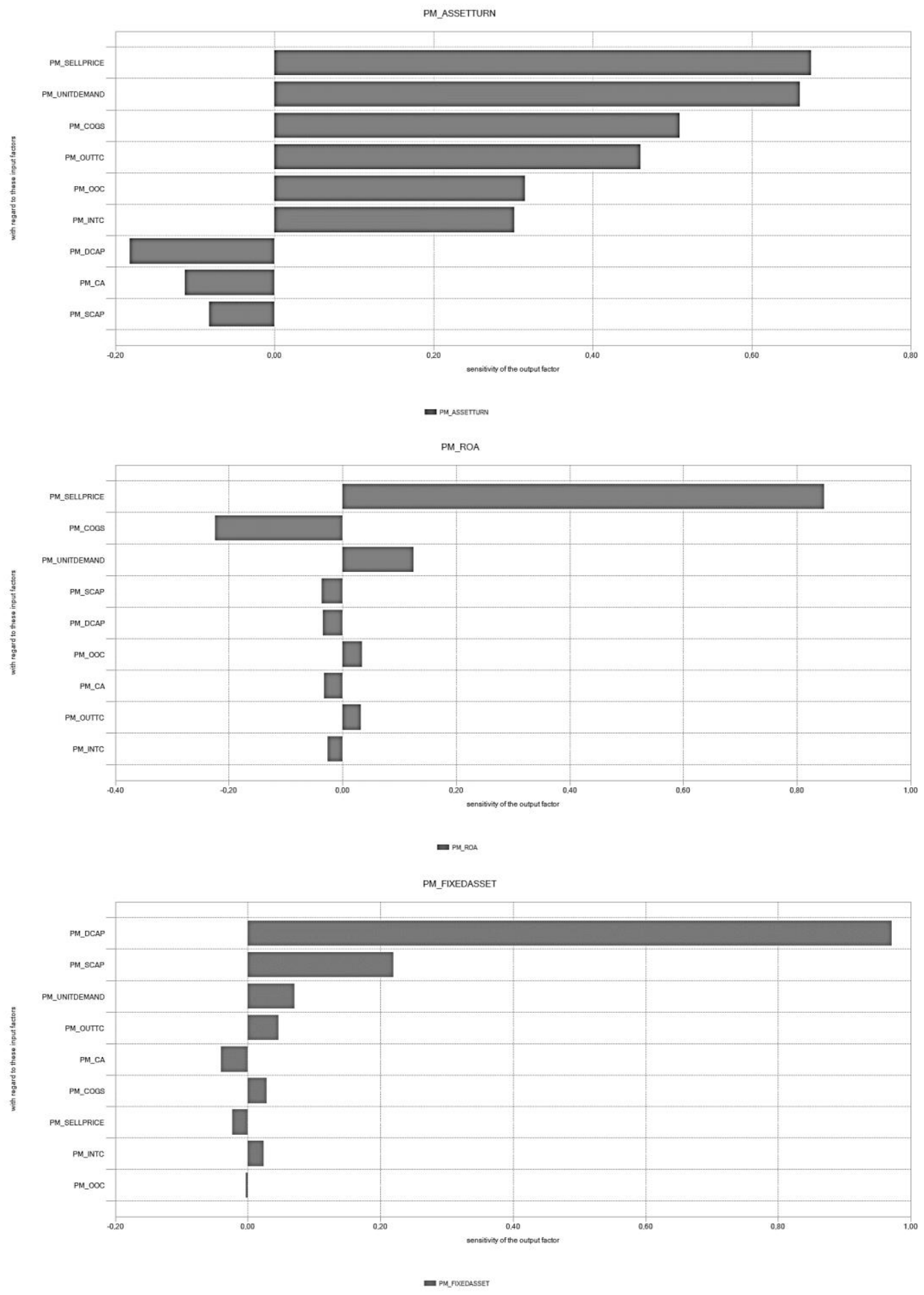